\begin{tabular}{|c|l|}
\hline Title & $\begin{array}{l}\text { Knockdown of the 7S globulin subunits shifts distribution of nitrogen sources to the residual protein fraction in } \\
\text { transgenic soybean seeds }\end{array}$ \\
\hline Author(s) & Y amada, Tetsuy a; Mori, Y oshihiro; Y asue, Kazuho; Maruy ama, Nobuy uki; Kitamura, Keisuke; A be, Jun \\
\hline Citation & $\begin{array}{l}\text { Plant cell reports, 33(12), 1963-1976 } \\
\text { https://doi.org/10.1007/300299-0141671-y }\end{array}$ \\
\hline Issue Date & 201412 \\
\hline Doc URL & http://hdl.handle.net/2115/60420 \\
\hline Rights & The final publication is available at link.springer.com \\
\hline Type & article (author version) \\
\hline File Information & Knockdown of the 7S globulin ....pdf \\
\hline
\end{tabular}

Instructions for use 


\title{
Knock-down of the 7S globulin subunits shifts distribution of nitrogen sources to the residual protein fraction in transgenic soybean seeds
}

Tetsuya Yamada · Yoshihiro Mori · Kazuho Yasue · Nobuyuki Maruyama ·

Keisuke Kitamura · Jun Abe

Y. Yamada $\cdot$ Y. Mori $\cdot$ K. Kitamura $\cdot$ J. Abe

Graduate School of Agriculture, Hokkaido University, Kita9 Nishi9, Kita-ku, Sapporo, Hokkaido 060-8589, Japan

K. Yasue

School of Agriculture, Hokkaido University, Kita9 Nishi9, Kita-ku, Sapporo, Hokkaido 060-8589, Japan

\section{N. Maruyama}

Graduate School of Agriculture, Kyoto University, Uji, Kyoto 611-011, Japan

Corresponding author: T. Yamada

Tel. +81 11 706-4186; fax +81 11 706-4933; e-mail: tetsuyay@ res.agr.hokudai.ac.jp

T. Yamada and Y. Mori contributed equally to this work.

Key message

A platform of gene silencing by amiRNA had been established in fertile transgenic soybean. We demonstrated that knock-down of storage protein shifted the distribution of nitrogen sources in soybean seeds.

\begin{abstract}
Artificial microRNAs (amiRNAs) were designed using the precursor sequence of the endogenous soybean (Glycine max L. Merrill) miRNA gma-miR159a and expressed in transgenic soybean plants to suppress the biosynthesis of $7 \mathrm{~S}$ globulin, which is one of the major storage proteins. Seed-specific expression of these amiRNAs (amiR-7S) resulted in a strong suppression of 7S globulin subunit genes and decreased accumulation of the 7S globulin subunits in seeds. Thus, the results demonstrate that a platform for gene silencing by amiRNA was first developed in fertile transgenic soybean plants. There was no difference in nitrogen, carbon, and lipid contents between amiR-7S and control seeds. Four protein fractions were collected from defatted mature seeds on the basis of solubility at
\end{abstract}


different $\mathrm{pH}$ to examine the distribution of nitrogen sources and compensatory effects. In the whey and lipophilic fractions, nitrogen content was similar in amiR-7S and control seeds. Nitrogen content was significantly decreased in the major soluble protein fraction and increased in the residual fraction (okara) of the amiR-7S seeds. Amino acid analysis revealed that increased nitrogen compounds in okara were proteins or peptides rather than free amino acids. Our study indicates that the decrease in $7 \mathrm{~S}$ globulin subunits shifts the distribution of nitrogen sources to okara in transgenic soybean seeds.

Keywords: Glycine max, amiRNA, gene silencing, storage protein, protein content, amino acids 


\section{Introduction}

Higher plants accumulate proteins, triglycerides and carbohydrates in sink tissues such as seeds, tubers, and tuberous roots. Dicotyledonous plants store considerable amounts of several families of storage proteins in seeds, which are mostly used as a source of carbon, nitrogen, and sulfur for seed germination and for the development of young seedlings (Herman and Larkins 1999). Soybean possesses high-quality proteins used as sources of food and forage worldwide. Therefore, protein content in mature seeds is often evaluated in wild and cultivated soybean germplasms, which vary widely in this respect (Kwanyuen et al. 1997; Zhang et al. 2010). Protein content in soybean seeds is a quantitatively inherited trait controlled by genotype and environmental interactions. Many quantitative trait loci affecting protein content of soybean seeds have been detected by genetic analyses of hybrid populations derived from numerous crosses (Diers et al. 1992; Mansur et al. 1996; Sebolt et al. 2000; Pathan et al. 2013). However, the mechanisms that control protein content in soybean seeds remain unknown.

Total protein content is determined by the accumulation of storage proteins in mature soybean seeds (Krishnan et al. 2007). Soybean seeds contain two major storage proteins, $\beta$-conglycinin (7S globulin) and glycinin (11S globulin); these proteins account for more than $50 \%$ of the total protein (Samoto et al. 2007; Schmidt et al. 2011). The 7S globulin is a heterotrimer or larger than a heterohexamer composed of three subunits: $\alpha, \alpha^{\prime}$, and $\beta$ (Thanh and Shibasaki 1978; Wadahama et al. 2012). The 11S globulin is a heterohexamer of several subunits: $A_{1 a} B_{1 b}, A_{1 b} B_{2}, A_{2} B_{1 a}, A_{3} A_{4}$, and $\mathrm{A}_{5} \mathrm{~A}_{4} \mathrm{~B}_{3}$ (Fischer and Goldberg 1982; Scallon et al. 1985; Nielsen et al. 1989). A number of spontaneous or inducible mutants deficient in $7 \mathrm{~S}$ or $11 \mathrm{~S}$ subunits have been reported (Mori et al. 1981; Kitamura et al. 1984; Takahashi et al. 1994; Hajika et al. 1996). These mutants have been often used to investigate the compensatory relations between $7 \mathrm{~S}$ and $11 \mathrm{~S}$ globulin subunits. A soybean mutant lacking all $11 \mathrm{~S}$ globulin subunits except $\mathrm{A}_{1 \mathrm{a}} \mathrm{B}_{1 \mathrm{~b}}$ has an increased accumulation of $7 \mathrm{~S}$ globulin subunits (Narikawa et al. 2010). This mutant has also several differences from the wild-type in the content of total protein and free amino acids (Narikawa et al. 2010). Biochemical and immunological analyses of a line that lacks the $\alpha$-subunit of $7 \mathrm{~S}$ globulin and has low content of the $\alpha$ - and $\beta$-subunits have revealed that the decrease in $7 \mathrm{~S}$ globulin is compensated by an increased abundance of $11 \mathrm{~S}$ globulin, with a strong negative correlation between the contents of $7 \mathrm{~S}$ and $11 \mathrm{~S}$ globulins (Ogawa et al. 1989). Total protein content of the lines with low 7S globulin content is slightly higher than that of wild-type plants (Ogawa et al. 1989).

The loss of major storage proteins is sometimes compensated by an increase in storage proteins other than 7S and 11S globulins or free amino acids, which serve as nitrogen sources. A soybean line lacking both $7 \mathrm{~S}$ and $11 \mathrm{~S}$ globulins, generated by crossbreeding of lines carrying mutations that confer a storage protein deficiency, has normal nitrogen content in mature seeds due to compensation by the increased amounts of free amino acids and other proteins such as lipoxygenase and sucrose-binding protein (Takahashi et al. 2003). The composition of major storage proteins has 
been also modified by post-transcriptional silencing of target genes mediated by RNA interference (RNAi) in transgenic soybean plants (Kinney et al. 2001; Nishizawa et al. 2010; Schmidt et al. 2011). Suppression of the $\alpha$ - and $\alpha^{\prime}$-subunits of 7S globulin increases the levels of the $\beta$-subunit and also those of the 11S globulin subunit precursors, P34 protein, and the vacuolar processing enzyme in transgenic soybean seeds (Kinney et al. 2001). RNAi-mediated gene silencing of 7S and 11S globulins increases the levels of other storage proteins such as P34, lectin, and Kunitz trypsin inhibitor (KTI) (Schmidt et al. 2011). In addition, the decrease in 7S globulin, 11S globulin, or both caused the formation of underdeveloped protein storage vacuoles (PSV) or the accumulation of endoplasmic reticulum (ER)-derived vesicles (a novel protein storage compartment) in soybean seeds (Kinney et al. 2001; Takahashi et al. 2003; Schmidt and Herman 2008). The composition of major storage proteins in soybean seed is closely associated with seed characteristics important for food processing, such as gel-forming and emulsifying properties (Nakamura et al. 1984; Tezuka et al. 2000; Maruyama et al. 2004). Several protein fractions from soybean seeds can be collected by using differences in protein solubility at different salt concentrations and $\mathrm{pH}$, and used to characterize the biochemical and physical properties of these proteins (Thanh and Shibasaki 1976; Iwabuchi and Yamaguchi 1987; Samoto et al. 2007). Characterization of the protein fractions from soybean seeds with modified composition of $7 \mathrm{~S}$ and $11 \mathrm{~S}$ globulins would reveal the mechanisms that control the compensatory relations between $7 \mathrm{~S}$ and $11 \mathrm{~S}$ globulins and the distribution of the nitrogen sources in soybean seeds.

There are two or more genes for each 7S globulin subunits, which are duplicated in the soybean genome and share considerable sequence similarity ( $\mathrm{Li}$ and Zhang 2011, Tsubokura et al. 2012). In this study, we generated transgenic soybean plants with reduced levels of 7S globulin subunits to investigate changes in the distribution of the nitrogen sources and total protein content. We attempted to induce silencing of the 7S globulin subunit genes by expressing artificial microRNAs (amiRNAs) in soybean seeds. We considered this approach feasible, because high sequence complementarity between amiRNA and target gene transcripts allows specific gene targeting despite the presence of several paralogs or orthologs (Shi et al. 2010b; Toppino et al. 2011). We have developed a platform for gene silencing mediated by amiRNA in fertile transgenic soybean plants. Four protein fractions in mature seeds of the transgenic soybean were separated on the basis of differences in protein solubility at different $\mathrm{pH}$ to investigate the distribution of nitrogen sources. Our results demonstrated that a decrease in $7 \mathrm{~S}$ globulin subunits shifts the distribution of nitrogen sources to the residual (okara) fraction.

\section{Materials and methods}

Cloning of the gma-miR159a precursor 
The precursor of gma-miRNA159a was chosen as the backbone for amiRNA expression. The precursor contains a stem loop of a moderate size (175 nucleotides) and a long transcribed region, and its expressed sequence tag is available in the NCBI database (http://www.ncbi.nlm.nih.gov/) as clone BM893181. Mature miRNA159a stem loop structure was retrieved from the published data (Zhang et al. 2008) and the miRBase database (http://www.mirbase.org/). A fragment that included the stem loop and a partial backbone sequence (435 nucleotides) based on the BM893181 sequence was amplified from cDNA of the Japanese soybean variety Kariyutaka using the primer set Gm-amiR_F1 and Gm-amiR_R3 (Table S1). The amplified fragment was subcloned into the pUC19 cloning vector. The amplified sequence was identified to that of BM893181.

Designing 7S globulin-specific amiRNAs and vector construction

According to the Phytozome database (http://www.phytozome.net/search.php), we used six genes, Glyma20g28650, Glyma20g28660, Glyma10g39150, Glyma10g39170, Glyma20g28460, and Glyma20g28640 as target genes for amiRNA-mediated knockdown. Three 21-nucleotide sequences, 5'-UGCCGAGAACAACCAGAGGAA-3', 5'-CAGUUUCUGUCUCAUUUGGCA-3', and 5'-CAAUUCCCAUUCCCACGCCCA-3', were chosen as the target sequences of the amiR-7S-A, amiR-7S-B, and amiR-7S-C, respectively, based on the sequence similarity of the six 7S globulin genes (Fig. 1a). The amiR-7S-C was designed to suppress the expression of only putative $\alpha$-subunit genes, Glyma20g28650 and Glyma20g28660. Specific primer sets (amiR-7S-A_R1, amiR-7S-A _F2, amiR-7S-A_R2, amiR-7S-A_F3, amiR-7S-B _R1, amiR-7S-B_F2, amiR-7S-B _R2, amiR-7S-B_F3, amiR-7S-C_R1, amiR-7S-C_F2, amiR-7S-C_R2, and amiR-7S-C_F3) were designed to replace antisense-miR159a (miR159a*) and miR159a with amiR-7S* and amiR-7S regions, respectively, in the gma-miRNA159a precursor (Table S1). The precursors of amiR-7S-A, amiR-7S-B, and amiR-7S-C, which contained the $\mathrm{Xba}$ I and Sac I restriction sites at the 5' and $3^{\prime}$ ends, respectively, were amplified by overlapping PCR (Fig. 1b). The precursor fragment of each 7S-amiR digested with $\mathrm{Xba}$ I and $\mathrm{Sac}$ I was inserted into the binary vector pMDC123-GFP (Sato et al. 2007). The cauliflower mosaic virus 35S (CaMV 35S) promoter, sGFP (Niwa et al. 1999), and nopalin synthase terminator in the binary plasmid vector were replaced by the $7 \mathrm{~S}$ globulin promoter (approximately $2.2 \mathrm{kbp}$ of the promoter region of Glyma20g28650 from the cultivar Williams82), the precursor of amiR-7S, and the terminator from an Arabidopsis (Arabidopsis thaliana L.) heat shock protein gene from the binary vector pRI 201-AN (TaKaRa Bio., Tokyo, Japan), respectively (Fig. 1b). The expression vectors encoding the precursors of amiR-7S-A, amiR-7S-B, and amiR-7S-C were designated as pamiR-7S-A, pamiR-7S-B, or pamiR-7S-C, respectively.

Plant material and transformation 
The Japanese soybean variety Kariyutaka was obtained from Hokkaido Prefectural Tokachi Agricultural Experiment Station, and was identical to the resource JP 86520 available from Genebank, National Institute of Agrobiological Science. Agrobacterium(Agrobacterium tumefaciens)-mediated transformation was performed according to the procedure of Yamada et al. (2010), with a modification: the cotyledonary node of each explant was wounded with a stainless steel surgical knife before the explants were prepared for infection with Agrobacterium harboring pamiR-7S-A, pamiR-7S-B, or pamiR-7S-C. Transgenic soybean plants expressing the precursors of amiR-7S-A, amiR-7S-B, or amiR-7S-C were named 7S-A, 7S-B, or 7S-C plants, respectively. A transgenic plant harboring only a selectable marker gene set (CaMV 35S promoter, phosphinothricin acetyltransferase gene [Bar], and CaMV polyA signal) was used as a control plant.

Storage protein analyses in mature seeds

Mature seeds were ground using a mortar and pestle. The powder $(5 \mathrm{mg})$ was suspended and vigorously mixed in $1 \mathrm{~mL}$ of protein extraction buffer (50 mM Tris- $\mathrm{HCl}, \mathrm{pH} 8.0,0.2 \%$ SDS, $5 \mathrm{M}$ urea, $2 \%$ 2-mercaptoethanol) for $10 \mathrm{~min}$. The suspension was centrifuged at 14,000 $\times g$ for $2 \mathrm{~min}$ and the supernatant $(4 \mu \mathrm{L})$ was subjected to SDS-PAGE in a 5-12\% gradient gel. Separated proteins were transferred to a PVDF membrane (Hybond-P; GE Healthcare, Little Chalfont, UK). Blots were blocked in a 5\% skim milk (Wako, Osaka, Japan) solution overnight at $4{ }^{\circ} \mathrm{C}$. Recombinant $\mathrm{A}_{1 \mathrm{a}} \mathrm{B}_{1 \mathrm{~b}}$ and $\mathrm{A}_{3} \mathrm{~B}_{4} 11 \mathrm{~S}$ globulin subunits were produced in Escherichia coli (Prak et al. 2005) and antisera were raised in rabbits against the recombinant proteins. Polyclonal antibodies specific to $7 \mathrm{~S}$ globulin $\alpha, \alpha^{\prime}$, and $\beta$ subunits were described previously (Mori et al. 2004; Nishizawa et al. 2003).Western blot and detection analyses were performed with the antisera described below and the ECL Plus Western Blotting system (GE Healthcare).

Southern blot analysis

Total DNA was isolated from fresh leaves (1.0-2.0 g) of 7S-A transgenic soybean plants $\left(\mathrm{T}_{2}\right)$ as described by Yamada et al. (2002). The digested DNA was transferred to a nylon membrane (Hybond-N+; GE Healthcare). The stem loop fragment of the amiR-7S-A precursor was used as a specific probe for Southern blot analysis using the primer set of amiR-7S-A_F2 and amiR-7S-A _R2 (Table S1) . Probe labeling, hybridization, and detection were carried out using the AlkPhos Direct Labeling System (GE Healthcare).

Expression analysis by quantitative RT-PCR (qRT-PCR)

Total RNA was extracted from developing $\mathrm{T}_{3}$ seeds (R6 stage) of 7S-A plants by the $\mathrm{LiCl}$ 
precipitation procedure (Dwiyanti et al. 2011) with several modifications. Immature seeds (approximately $300 \mathrm{mg}$ ) were ground into a fine powder in liquid nitrogen using a mortar and pestle. The powder was mixed with $600 \mu \mathrm{L}$ of RNA extraction buffer $(10 \mathrm{mM}$ Tris-HCl, pH 7.5, $1 \mathrm{mM}$ EDTA, pH 8.0, $100 \mathrm{mM} \mathrm{NaCl}, 1 \%$ SDS) and $300 \mu \mathrm{L}$ of Tris-saturated phenol (pH 8.0). Chloroform:isoamyl alcohol $(24: 1[\mathrm{v} / \mathrm{v}] ; 300 \mu \mathrm{L})$ was added to the sample, the solution was mixed vigorously, and the aqueous and organic layers were separated by centrifugation at 20,000 $\times g$ for 10 min. RNA was precipitated by the addition of 0.3 volumes of $8 \mathrm{M} \mathrm{LiCl}$. Removal of DNA by DNase I and cDNA synthesis from purified total RNA were carried out as described by Dwiyanti et al. (2011).

QRT-PCR was conducted in a $20-\mu \mathrm{L}$ volume containing $9.2 \mu \mathrm{L}$ of diluted cDNA solution, $0.8 \mu \mathrm{L}$ of each primer $(1 \mu \mathrm{M})$ and $10 \mu \mathrm{L}$ of SYBR Premix Ex Taq II (Tli RNaseH Plus) (TaKARa Bio.). The reaction was performed in a CFX96 Real-Time System (Bio-Rad Laboratories Inc., Tokyo, Japan) under the following conditions: 40 cycles of $95^{\circ} \mathrm{C}$ for $30 \mathrm{~s}, 56^{\circ} \mathrm{C}$ for $30 \mathrm{~s}$ and $72^{\circ} \mathrm{C}$ for $30 \mathrm{~s}$. The specificity of amplification was verified by melting-curve analysis. The expression levels of $7 \mathrm{~S}$ globulin genes were normalized to that of the $\beta$-tubulin gene. On the basis of sequence similarity, expression analyses of 7S globulin genes were evaluated as Glyma20g28650 plus Glyma20g28660, Glyma10g39150, Glyma10g39170, and Glyma20g28460 plus Glyma20g28640. Primers used for each 7S globulin gene, endogenous gma-miRNA159a, and $\beta$-tubulin were as follows:

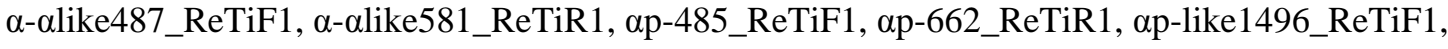

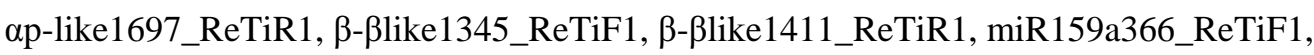
miR159a461_ReTiR1, $\beta$-tubulinF1, and $\beta$-tubulinR1 (Table S1).

Northern blot analysis

Low-molecular-weight (LMW) RNA was isolated from $\mathrm{T}_{3}$ immature seeds of a 7S-A-2 plant as described by Goto et al. (2003), with some modifications. Immature seeds (approximately $300 \mathrm{mg}$ ) were ground into a fine powder in liquid nitrogen using a mortar and pestle. The powder was mixed with $3 \mathrm{~mL}$ of LMW RNA extraction buffer (100 mM Tris-HCl, pH 8.0, 20 mM EDTA, $200 \mathrm{mM}$ $\mathrm{NaCl}, 4 \% \mathrm{~N}$-lauroyl sarcosine, $16 \mathrm{mM}$ dithiothreitol). The mixture was vigorously mixed with $3 \mathrm{~mL}$ of phenol:chloroform:isoamyl alcohol (PCI; 25:24:1 v/v). The aqueous phase was separated by centrifugation $2,000 \times g$ for $5 \mathrm{~min}$, again mixed with $3 \mathrm{~mL}$ of PCI, and the centrifugation was repeated. The aqueous phase was and mixed in 0.3 volumes of $8 \mathrm{M} \mathrm{LiCl}$ and the mixture was kept in crushed ice overnight. Nucleic acids were precipitated with ethanol from the upper phase separated from the LiCl mixture. LMW RNA was collected from the nucleic acid solution by polyethylene glycol precipitation.

LMW RNAs were separated in a denaturing $14.3 \%$ polyacrylamide gel. Separated RNAs were transferred to a nylon membrane (Hybond-N+; GE Healthcare). A 21-nucleotide probe was designed 
to detect the production of amiR-7S and labeled using a DIG Oligonucleotide 3'-End Labeling Kit, $2^{\text {nd }}$ Generation (Roche Diagnostics, Mannheim, Germany).

Measurement of nitrogen and carbon contents of mature seeds

Seeds of 7S-A plants were kept for more than 10 days in a desiccator to remove extra moisture. The seed coat was removed with a surgical knife. Embryos without a seed coat were ground using a mortar and pestle. The fine powder was used for measurements of nitrogen and carbon contents using a Micro Corder JM10 (J-Science Lab Co., Kyoto, Japan). These analyses were supported by the Instrumental Analysis Division, Equipment Management Center, Creative Research Institution, Hokkaido University.

Measurement of lipid content

Mature $\mathrm{T}_{3}$ seeds of $7 \mathrm{~S}$-A plants were ground using a mortar and pestle. Fatty acids were analyzed according to the method of Shibata et al. (2008). Lipid content was calculated as the total fatty acid content (palmitic, oleic, linoleic, and linolenic acids) determined by gas chromatography based on the ratio of the areas of respective peaks to that of heptadecanoic acid.

Fractionation of mature seed protein

Fractionation of seed protein of 7S-A plants was performed according to the patent JP 2010-193909 with some modifications (Fig. S1). Mature $\mathrm{T}_{3}$ seeds were kept for 2 weeks with silica gels in a desiccator. Soybean meal (grinded seed; $130 \mathrm{mg}$ ) was mixed vigorously with $780 \mu \mathrm{L}$ of hexane to defat the meal. The mixture was incubated at $40^{\circ} \mathrm{C}$ for $5 \mathrm{~min}$. The aqueous phase was removed after centrifugation at $1,000 \times g$ for $5 \mathrm{~min}$. Defatting was performed twice. Defatted soymeal $(100 \mathrm{mg})$ was resuspended in $700 \mu \mathrm{L}$ of water, adjusted to $\mathrm{pH} 7.5$ with $\mathrm{NaOH}$, mixed vigorously for $30 \mathrm{~min}$, and centrifuged at $1,000 \times g$ for $10 \mathrm{~min}$. The precipitate was resuspended in $500 \mu \mathrm{L}$ of distilled water, mixed vigorously for $30 \mathrm{~min}$, and centrifuged at $1,000 \times g$ for $10 \mathrm{~min}$. The precipitate and the supernatant from these two fractionations were considered as the residual fraction and defatted soymilk, respectively. Defatted soymilk was adjusted to $\mathrm{pH} 4.5$ with $\mathrm{HCl}$, and mixed with a final concentration of $1.4 \%$ 2-mercaptoethanol for $10 \mathrm{~min}$ at room temperature. The mixture was centrifuged at $1,000 \times g$ for $10 \mathrm{~min}$. The supernatant was considered as the whey fraction. The precipitate was resuspended in $250 \mu \mathrm{L}$ of water containing 1.4\% 2-mercaptoethanol and mixed vigorously for $10 \mathrm{~min}$. During mixing, $250 \mu \mathrm{L}$ of $2 \mathrm{M}$ sodium sulfate containing $1.4 \%$ 2-mercaptoethanol was gradually added, and the suspension was mixed vigorously for a further 10 min and centrifuged at $10,000 \times g$ for $20 \mathrm{~min}$. The supernatants and the precipitates from the two 
fractionations were considered as the MSP fraction and LP fraction, respectively. The $\mathrm{pH}$ of each sample was measured with a compact $\mathrm{pH}$ meter (LAQUAtwin B-712; Horiba, Kyoto, Japan).

Analyses of protein fractions of mature seeds

The residual, whey, MSP, and LP fractions were used to measure the nitrogen content and to analyze the protein distribution. Nitrogen content was measured by a Micro Corder as described above for mature seeds. For protein analysis, each fraction was suspended in protein extraction buffer as for protein analysis in mature seeds. Proteins in each the residual, the whey, the MSP, and the LP fraction were separated by SDS-PAGE. Separated proteins were evaluated by Coomassie Brilliant Blue (CBB) staining.

Amino acid analysis in the residual fraction of mature seeds

The residual fraction from 7S-A plants was used for total and free amino acid analyses. Free amino acids were extracted from the freeze-dried residual fraction by homogenization in $75 \%$ ethanol. The extract was filtered and subjected to amino acid analysis. Amino acids were analyzed by the post-column ninhydrin detection method using one of two automatic amino acid analyzers JLC-500/V (Nihondennshi, Tokyo, Japan) or L-8900 (Hitachi High-Technologies Co, Tokyo, Japan). Total amino acids were first treated by an oxidation with performic acid at $4^{\circ} \mathrm{C}$ for 16 hours. The oxidized samples were hydrolyzed with $6 \mathrm{M}$ hydrochloric acid $110^{\circ} \mathrm{C}$ for 24 hours and analyzed on one of the amino acid analyzers. Tryptophan content was evaluated in the oxidized samples hydrolyzed with $3 \mathrm{M}$ mercaptoethanesulfonic acid at $110^{\circ} \mathrm{C}$ for 22 hours . All analyses were supported by the Instrumental Analysis Division, Equipment Management Center Creative Research Institution, Hokkaido University.

Biological replicates in the above measurement of seed components

Carbon, nitrogen, lipid, and amino acid contents in mature seeds and/or protein fractions were shown as means and standard deviation for three biological replicates of each amiR-7S-A and control plants. These transgenic plants were grown under the condition at $23^{\circ} \mathrm{C}$ for 16 hours photoperiod.

Electron microscopic immunocytochemistry of mature seeds

Cotyledons from 7S-A and control plants were fixed for $2 \mathrm{~h}$ in $4 \%(\mathrm{v} / \mathrm{v})$ formaldehyde, $0.05 \%(\mathrm{v} / \mathrm{v})$ glutaraldehyde solution at $4^{\circ} \mathrm{C}$. The tissues were washed in $100 \mathrm{mM}$ sodium phosphate $(\mathrm{pH} 7.2)$, dehydrated in a graded ethanol series, and embedded in LR White resin (London Resin, Basingstoke, 
UK). Ultrathin sections were cut with a glass knife and mounted on formvar/carbon-coated grids. The sections were blocked with $1 \%(\mathrm{w} / \mathrm{v})$ BSA in PBS and incubated with antisera specific to the A1aB1b subunit of $11 \mathrm{~S}$ globulin in $1 \%(\mathrm{w} / \mathrm{v})$ BSA-PBS. The sections were washed with $1 \%(\mathrm{w} / \mathrm{v})$ BSA-PBS and incubated with a secondary antibody conjugated to 15-nm gold (BBI Solutions, Cardiff, UK) in 1\% (w/v) BSA-PBS at room temperature. After washing, sections were stained with $4 \%(\mathrm{w} / \mathrm{v}$ ) uranyl acetate and $80 \mathrm{mM}$ lead nitrate. The grids were examined with a transmission electron microscope (model H-7100; Hitachi, Tokyo, Japan).

Statistical analysis

A statistical $F$ test was performed to evaluate the population variances among all samples. The Student's $t$ test or the Welch's $t$ test were used to examine whether population means are significantly different from amiR-7S and control plants. All statistic data was evaluated significantly different from the control when $P$ values were $<0.05$. The asterisks in the Figures and Tables indicate statistical significance: $* P<0.05$; ** $P<0.01$; with respect to the control.

\section{Results}

Accumulation level and composition of storage proteins in mature seeds

We examined the composition of storage proteins in mature $T_{2}$ or $T_{3}$ seeds of nine amiR-7S plants (7S-A, 7S-B, and 7S-C). The SDS-PAGE profiles showed a large change in the distribution of 7S globulin subunits (Fig. 2a). In five plants (7S-A-2, 7S-A-5, 7S-B-1, 7S-B-2, and 7S-B-10), accumulation of all 7S globulin subunits was strongly suppressed (Fig. 2b). The accumulation of the $\alpha$-subunit decreased in 7S-C-1 and 7S-C-4 plants, whereas the accumulation of the $\beta$-subunit in 7S-C-2 and 7S-C-4 was higher than in the control seeds (Fig. 2b). All 7S-A, 7S-B, and 7S-C plants showed normal plant height, plant shape, seed shape, and seed size. Three 7S-A plants, which expressed the precursor of amiR-7S-A with the highest sequence complementarity to the transcripts of target genes among the amiR-7S series (Fig. 1a), were used in further analyses. Southern blot analysis revealed that one to six transgene copies were integrated into the genomes of the 7S-A plants (Fig. S2).

Expression levels of the 7S globulin subunit genes

The expression levels of the 7S globulin genes were evaluated in immature $T_{2}$ seeds of three $T_{1}$ plants (7S-A-1, 7S-A-2, and 7S-A-5). Glyma20g28650 and Glyam20g28660 were considered as $\alpha$-subunit genes. The expression level of the $\alpha$-subunit genes, evaluated as the sum of the two 
transcripts because of their high sequence similarity, was 5\% lower in the 7S-A seeds than in the control seeds (Fig. 3a). Glyma10g39150, considered as an $\alpha^{\prime}$-subunit gene, was also strongly down-regulated in 7S-A seeds (Fig. 3b). On the other hand, Glyma10g39170, which encodes the other $\alpha^{\prime}$-subunit isoform, was strongly suppressed only in 7S-A-2 (Fig. 3c). Glyma20g28460 and Glyma20g28640 were considered as $\beta$-subunit genes. The expression level of the $\beta$-subunit genes, evaluated as the sum of the two transcripts because of their high sequence similarity, was much lower in 7S-A seeds than in the control seeds (Fig. 3d).

Expression levels of endogenous gma-miR159a and amiR-7S-A

The design of amiR-7S-A was based on the precursor of endogenous soybean gma-miR159a (Fig. 1b). Over-expression of a gene sometimes causes suppression of both endogenous and exogenous genes (Napoli et al. 1990; Kinney et al. 2001). Suppressed expression of endogenous gma-miR159a would seriously damage the development and growth of 7S-A plants, because the miR159 family (which includes miR159a and miR159b) controls the expression of several transcription factors associated with pleiotropic morphological effects or programmed cell death in Arabidopsis (Allen et al. 2007; Alonso-Peral et al. 2010). Therefore, we examined the expression level of endogenous gma-miR159a in the 7S-A-2 plant, which showed the strongest suppression of all six 7S globulin subunit genes (Fig. 2). We designed the specific prime set to detect the transcript of gma-miR159a (Fig. 4a). We found no statistically significant difference in the gma-miR159a expression levels between 7S-A-2 and control seeds (Fig. 4b). Northern blot analysis using the specific probe for amiR-7S-A revealed that the 7S-A-2 plant produced amiR-7S-A (Fig.4a, c).

Levels of nitrogen, carbon, and lipids in mature seeds

Large changes in storage protein composition might decrease the protein content in mature seeds. Therefore, we evaluated nitrogen content in mature $\mathrm{T}_{3}$ seeds of $7 \mathrm{~S}$-A plants, and found no significant difference from control seeds (Fig. 5a). Nitrogen content of soybean seeds is generally converted to crude protein content by multiplying by 6.25 . According to this formula, the crude protein contents were $40.4 \pm 0.8(\%), 44.3 \pm 2.2,41.6 \pm 0.4$, and $43.0 \pm 2.2$ in the control, 7S-A-1, 7S-A-2, and 7S-A-5 seeds, respectively. We also evaluated the carbon content in mature seeds of 7S-A and control plants, and found that it was approximately 50\% in all seeds (Fig. 5b). A strongly negative relationship has been reported between the lipid and protein contents in mature soybean seeds (Brim and Burton 1979; Cober and Voldeng 2000; Shi et al. 2010a). In line with similar protein content in all 7S-A seeds, there was no significant difference in lipid content in 7S-A and control plants (Fig. 5c). Fatty acid composition (percentage of total fatty acids) was the similar in mature seeds of all plants (data not shown). 
Nitrogen levels in protein fractions of defatted soymeal

There was no significant difference in the nitrogen content between 7S-A and control seeds (Fig. 5a), although SDS-PAGE analysis showed a decreased accumulation of $7 \mathrm{~S}$ globulin subunits in 7S-A seeds (Fig. 2). We examined the distribution of proteins in the whey, residual, major soluble protein (MSP), and lipophilic (LP) fractions of defatted soymeal (Fig. S1). There was no significant difference in the nitrogen content in the whey fraction (Fig. 6a). Nitrogen content per $100 \mathrm{mg}$ defatted soymeal was decreased by approximately $0.96 \pm 0.16 \mathrm{mg}$ in the MSP fraction from the 7S-A plants in comparison with control plants (Fig. 6b). Nitrogen content in the residual fraction from 7S-A seeds was higher than in that from control seeds (Fig. 6c). There was no change in the nitrogen content in the LP fraction (Fig. 6d).

Protein distribution in fractions from defatted soymeal

To confirm changes in protein distribution, we evaluated SDS-PAGE profiles of protein fractions from 7S-A-2 plants, which had the strongest suppression of 7S subunit accumulation. There was no appreciable differences except slight accumulation of $7 \mathrm{~S}$ globulin subunits in the residual fraction between 7S-A and control seeds (Fig. S3). A marked decrease in 7S globulin subunits was observed in the MSP fraction of 7S-A seeds (Fig. S3). There were no considerable differences between 7S-A and control seeds in protein composition of the whey and LP fractions (Fig. S3).

Amino acid content and composition in the residual fraction of defatted soymeal

We examined the content and composition of amino acids in the residual fractions from 7S-A-1 and 7S-A-2 seeds. Most amino acids, except aspartic acid (whose content is a sum of asparagine and aspartic acid) and cysteine, were increased significantly in 7S-A seeds (Table 1). As a result, total amino acid content of $7 \mathrm{~S}$-A seeds $(11.475 \pm 1.401$ and $10.722 \pm 0.356 \mathrm{mg} / 100 \mathrm{mg}$ defatted soymeal in

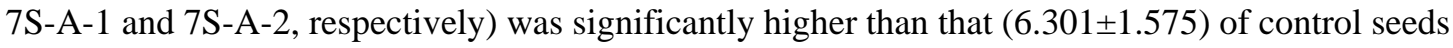
(Table 1).

We also analyzed the composition of free amino acids in the residual fractions of 7S-A and control seeds. Many amino acids (except aspartic acid, cysteine, isoleucine, leucine, and methionine) were increased significantly in 7S-A seeds (Table S2). Free amino acids content of 7S-A seeds $(151.724 \pm 35.551$ and $125.403 \pm 15.159 \mu \mathrm{g} / 100 \mathrm{mg}$ defatted meal in $7 \mathrm{~S}-\mathrm{A}-1$ and $7 \mathrm{~S}-\mathrm{A}-2$, respectively) was much higher than that (49.237 \pm 8.329$)$ of control seeds (Table S2).

We calculated the nitrogen content based on the content of each amino acid in the residual fractions of the 7S-A and control seeds. Nitrogen content derived from total amino acid content was 
increased significantly in the 7S-A seeds $(1.62 \pm 0.215$ and $1.51 \pm 0.047 \mathrm{mg} / 100 \mathrm{mg}$ defatted meal in 7S-A-1 and 7S-A-2, respectively) in comparison with the control seeds $(0.874 \pm 0.223)$ (Fig. 7a). Nitrogen content derived from free amino acids was also higher in 7S-A seeds $(0.036 \pm 0.001$ and $0.029 \pm 0.004 \mathrm{mg} / 100 \mathrm{mg}$ defatted meal in 7S-A-1 and 7S-A-2, respectively) than in the control seeds $(0.009 \pm 0.001)$ (Fig. $7 b)$. These results indicate that total amino acids strongly contribute to the difference in nitrogen content between the residual fractions from the 7S-A and control seeds.

Quantitative changes in 11S globulin subunits and their localization in mature seeds

The abundance of two precursors of 11S globulin subunits (ProGY1 and ProGY5) was slightly increased in mature 7S-A seeds in comparison with control seeds (Fig. S4). However, there were no differences in the amounts of $\mathrm{A}_{1 \mathrm{a}} \mathrm{B}_{1 \mathrm{~b}}$ and $\mathrm{A}_{3} \mathrm{~A}_{4}$ subunits between 7S-A and control seeds (Fig. S4). We also examined organelle morphology in mature seeds by electron microscopy, and found no differences in PSV and oil body morphology between the 7S-A and control seeds (Fig. 8a, b). Immunoelectron microscopic analysis showed that mature $7 \mathrm{~S}-\mathrm{A}$ seed accumulated $\mathrm{A}_{1 \mathrm{a}} \mathrm{B}_{1 \mathrm{~b}}$ subunit preferentially in PSV (Fig. 8c).

\section{Discussion}

Gene silencing mediated by amiRNA has been used in many higher plants such as Arabidopsis, rice (Oryza sativa L.), Populus (Populus trichocarpa Torr. \& Gray), tomato (Solanum lycopersicum L.), tobacco (Nicotiana tabacum L.), eggplant (Solanum melongena L.), and wheat (Triticum aestivum L.) to verify the functions of target genes (Niu et al. 2006; Warthmann et al. 2008; Shi et al. 2010b; Fernandez et al. 2009; Ai et al. 2011; Toppino et al. 2011; Fahim et al. 2012). These amiRNAs, which were efficiently expressed mediated by the production process of endogenous miRNA, have induced the strong suppressive effect of target gene in various plant species, indicating that amiRNAs were a powerful tool to analyze gene functions in transgenic plants. There have been no reports on the production of fertile transgenic soybean plants expressing amiRNA, although a transmembrane receptor kinase gene was knocked down in transgenic soybean roots to examine the relationship between its expression level and resistance to cyst nematode (Heterodera glycines Ichinohe) (Melito et al. 2011). In our study, the expression of three amiRs (amiR-7S-A, amiR-7S-B, and amiR-7S-C) resulted in large changes in the composition of $7 \mathrm{~S}$ globulin subunits in transgenic soybean seeds. Thus, we have developed a platform for gene silencing by amiRNA in fertile transgenic soybean plants. Interestingly, 7S-B plants had the same composition of 7S globulin subunits as 7S-A plants: in both cases, accumulation of all subunits $\left(\alpha, \alpha^{\prime}\right.$, and $\left.\beta\right)$ was strongly suppressed (Fig. 2). Although amiR-7S-B has a high sequence complementarity to the transcripts of two $\alpha$ - and one $\alpha^{\prime}$-subunit genes, there was a mismatch of five and six nucleotides between amiR-7S-B and the transcripts of one $\alpha^{\prime}$ - and two $\beta$-subunit genes, respectively (Fig. 1a). Although 
the sequences of both amiR-7S-A and amiR-7S-C were completely complementary to the $\alpha$-subunit transcripts, the $\alpha$-subunit accumulated differently in 7S-A and 7S-C plants (Fig. 1a). This suggests that the strength or specificity of gene silencing mediated by amiRNA might depend on the target position, the amiRNA sequence matching the target transcript, or both. We could not clarify the relation between the suppressive effect for the target gene and the sequence complementarity of the amiRNA to transcript of the target gene in this study. Therefore, understanding this relation will lead to establish a stable platform of gene silencing mediated by amiRNAs in higher plants.

Accumulation of the $\alpha$-subunit in mature seeds of 7S-C plants was reduced (Fig. 2). The level of the $\beta$-subunit in 7S-C plant was slightly higher than that in control plants (Fig. 2), indicating a compensatory relation between these $7 \mathrm{~S}$ globulin subunits. The increase in the $\beta$-subunit has been also observed in transgenic soybean seeds with decreased levels of $\alpha$ - and $\alpha^{\prime}$-subunits (Kinney et al. 2001). Accumulation of the $\beta$ subunit was sensitive to the concentration of amino acids supplied to the seeds (Ohtake et al. 1997; Allen and Young 2013). This indicates that the $\beta$-subunit levels may be more responsive to changes in nitrogen sources (proteins and amino acids) than those of the $\alpha$ and $\alpha^{\prime}$-subunits as well as previous reports described by Ohtake et al. (1997) and Allen and Young (2013). A compensatory relation between 7S and 11S globulins has been observed when the composition of globulins was altered (Ogawa et al. 1989; Narikawa et al. 2010). In our study, the levels of $11 \mathrm{~S}$ globulin subunits in 7S-A seeds were the same as or slightly higher than those in control seeds (Fig. S4). However, nitrogen content in the MSP fraction of 7S-A seeds was much lower than that of control seeds, although there was no difference in nitrogen content in whole seeds (Fig. 5, Fig. 6). This indicates that there was little nitrogen source compensation by an increase in 11S globulins in the MSP fraction.

Many other proteins such as P34, lectin, KTI, basic 7S globulin, lipoxygenase, and sucrosebinding protein compensate for the decrease in nitrogen sources in seeds with decreased 7S and 11S globulin levels (Kinney et al. 2001; Takahashi et al. 2003; Schmidt et al. 2011). Lectin and KTI were mainly found in the whey fraction (Sorgentini and Wagner 1999), whereas P34 and lipoxygenase were mainly detected in the LP fraction (Samoto et al. 1998). Our results show that there was no difference between the 7S-A and control seeds in the nitrogen content and protein distribution in the whey and LP fractions (Fig. 6a, d, Fig. S3). On the other hand, nitrogen content was significantly decreased in the MSP fraction and increased in the residual fraction of the 7S-A seeds (Fig. 6b, c). Determination of the nitrogen content in each fraction revealed that the decrease in nitrogen sources in the MSP fraction was compensated for by an increase in nitrogen sources in the residual fraction in the 7S-A seeds. Amino acid analysis revealed that increased amino acids in the residual fraction of the 7S-A seeds were derived from proteins or peptides but were not free amino acids (Table 1, Table S2). The increase in nitrogen sources in the residual fraction of 7S-A seeds was mostly derived from the increase in total amino acids (Fig. 7a). These findings indicate that the decrease in $7 \mathrm{~S}$ globulin subunits was compensated for by a nitrogen source from a protein or peptides distributed into the 
residual fraction of the 7S-A seeds. However, the SDS-PAGE profiles revealed no considerable increase in the abundance of any proteins in the residual fraction of 7S-A seeds in comparison with that of control seeds (Fig. S3). Nitrogen sources that increased in the residual fraction of the 7S-A seeds might be proteins that are not efficiently stained with $\mathrm{CBB}$; alternatively, these nitrogen sources may be derived from short peptides. Kinney et al. (2001) have demonstrated that one of $11 \mathrm{~S}$ globulin precursors accumulated in the ER-derived vesicles in transgenic soybean seeds with decreased 7S globulin subunit levels. ProGYs were increased slightly in 7S-A seeds, but no such structures were observed in 7S-A seeds by electron microscopic immunological analyses (Fig. 8, Fig. S4).

The residual fraction obtained during soybean processing is generally known as 'okara'. Dried okara has a good nutritional value, because it contains about $50 \%$ of fiber, $25 \%$ of protein, and $10 \%$ of lipids (Vanderriet et al. 1989; Redondo-Cuenca et al. 2008; Mateos-Aparicio et al. 2010). Therefore, okara is used as a functional food or for livestock feeding. We demonstrated that a decrease in $7 \mathrm{~S}$ globulin subunits shifted the distribution of nitrogen sources to the okara fraction. Modification of the major storage protein composition may extend the use of the protein fraction other than the MSP.

\section{Acknowledgments}

We thank Y. Kitsui and M. Suzuki (Hokkaido University), and E. Okuda (Kyoto University) for technical assistance. This work was supported in part by Grants-in-Aid for Scientific Research from the Ministry of Education, Culture, Sports, Science and Technology of Japan (23580002) and by CREST of the Japan Science and Technology Agency (JAT).

\section{Conflict of interest}

The authors declare that they have no conflict of interest.

\section{Author contribution}

TY, KK, and JA conceived and designed research. TY, YM, KY, and NM conducted experiments. TY and YM analyzed data. TY wrote the manuscript. All authors read and approved the manuscript.

\section{References}

Ai T, Zhang L, Gao Z, Zhu CX, Guo X (2011) Highly efficient virus resistance mediated by artificial microRNAs that target the suppressor of PVX and PVY in plants. Plant Biol 13:304-316. doi:10.1111/j.1438-8677.2010.00374.x

Allen DK, Young JD (2013) Carbon and nitrogen provisions alter the metabolic flux in developing soybean embryos. Plant Physiol 161:1458-1475. doi:10.1104/pp.112.203299 
Allen RS, Li J, Stahle MI, Dubroue A, Gubler F, Millar AA (2007) Genetic analysis reveals functional redundancy and the major target genes of the Arabidopsis miR159 family. Proc Natl Acad Sci USA 104:16371-16376. doi:10.1073/pnas.0707653104

Alonso-Peral MM, Li J, Li Y, Allen RS, Schnippenkoetter W, Ohms S, White RG, Millar AA (2010) The microRNA159-regulated GAMYB-like genes inhibit growth and promote programmed cell death in Arabidopsis. Plant Physiol 154:757-771. doi:10.1104/pp.110.160630

Brim CA, Burton JW (1979) Recurrent selection in soybeans .2. selection for increased percent protein in seeds. Crop Sci 19:494-498

Cober ER, Voldeng HD (2000) Developing high-protein, high-yield soybean populations and lines. Crop Sci 40:39-42

Diers BW, Keim P, Fehr WR, Shoemaker RC (1992) RFLP analysis of soybean seed protein and oil content. Theor Appl Genet 83:608-612

Dwiyanti MS, Yamada T, Sato M, Abe J, Kitamura K (2011) Genetic variation of gamma-tocopherol methyltransferase gene contributes to elevated alpha-tocopherol content in soybean seeds. BMC Plant Biol 11. doi:10.1186/1471-2229-11-152

Fahim M, Millar AA, Wood CC, Larkin PJ (2012) Resistance to wheat streak mosaic virus generated by expression of an artificial polycistronic microRNA in wheat. Plant Biotechnol J 10:150-163. doi:10.1111/j.1467-7652.2011.00647.x

Fernandez AI, Viron N, Alhagdow M, Karimi M, Jones M, Amsellem Z, Sicard A, Czerednik A, Angenent G, Grierson D, May S, Seymour G, Eshed Y, Lemaire-Chamley M, Rothan C, Hilson P (2009) Flexible tools for gene expression and silencing in tomato. Plant Physiol 151:1729-1740. doi:10.1104/pp.109.147546

Fischer RL, Goldberg RB (1982) Structure and flanking regions of soybean seed protein genes. Cell 29:651-660. doi:10.1016/0092-8674(82)90181-7

Goto K, Kanazawa A, Kusaba M, Masuta C (2003) A simple and rapid method to detect plant siRNAs using nonradioactive probes. Plant Mol Biol Rep 21:51-58. doi:10.1007/bf02773396

Hajika M, Takahashi M, Sakai SJ, Igita K (1996) A new genotype of 7 S globulin (beta-conglycinin) detected in wild soybean (Glycine soja Sieb et Zucc). Breed Sci 46:385-386

Herman EM, Larkins BA (1999) Protein storage bodies and vacuoles. Plant Cell 11:601-613

Iwabuchi S, Yamauchi F (1987) Electrophoretic analysis of whey proteins present in soybean globulin fractions. J Agric Food Chem 35:205-209. doi:10.1021/jf00074a010

Kinney AJ, Jung R, Herman EM (2001) Cosuppression of the alpha subunits of beta-conglycinin in transgenic soybean seeds induces the formation of endoplasmic reticulum-derived protein bodies. Plant Cell 13:1165-1178. doi:10.1105/tpc.13.5.1165

Kitamura K, Davies CS, Nielsen NC (1984) Inheritance of alleles for cgy1 and gy4 storage protein genes in soybean. Theo Appl Genet 68:253-257. doi:10.1007/bf00266899

Krishnan HB, Natarajan SS, Mahmoud AA, Nelson RL (2007) Identification of glycinin and 
beta-conglycinin subunits that contribute to the increased protein content of high-protein soybean lines. J Agric Food Chem 55:1839-1845. doi:10.1021/jf062497n

Kwanyuen P, Pantalone VR, Burton JW, Wilson RF (1997) A new approach to genetic alteration of soybean protein composition and quality. J Am Oil Chem Soc 74:983-987. doi:10.1007/s11746-997-0015-2

Li C, Zhang YM (2011) Molecular evolution of glycinin and beta-conglycinin gene families in soybean (Glycine max L. Merr.). Heredity 106:633-641. doi:10.1038/hdy.2010.97

Mansur LM, Orf JH, Chase K, Jarvik T, Cregan PB, Lark KG (1996) Genetic mapping of agronomic traits using recombinant inbred lines of soybean. Crop Sci 36:1327-1336

Maruyama N, Prak K, Motoyama S, Choi SK, Yagasaki K, Ishimoto M, Utsumi S (2004)

Structure-physicochemical function relationships of soybean glycinin at subunit levels assessed by using mutant lines. J Agric Food Chem 52:8197-8201. doi:10.1021/jf048786y

Mateos-Aparicio I, Mateos-Peinado C, Ruperez P (2010) High hydrostatic pressure improves the functionality of dietary fiber in okara by-product from soybean. Innovative Food Science \& Emerging Technologies 11:445-450. doi:10.1016/j.ifset.2010.02.003

Melito S, Heuberger AL, Cook D, Diers BW, MacGuidwin AE, Bent AF (2010) A nematode demographics assay in transgenic roots reveals no significant impacts of the Rhg1 locus LRR-Kinase on soybean cyst nematode resistance. BMC Plant Biol 10. doi:

10.1186/1471-2229-10-104

Mori T, Maruyama N, Nishizawa K, Higasa T, Yagasaki K, Ishimoto M, Utsumi S (2004) The composition of newly synthesized proteins in the endoplasmic reticulum determines the transport pathways of soybean seed storage proteins. Plant J 40:238-249. doi:10.1111/j.1365-313X.2004.02204.x

Mori T, Utsumi S, Inaba H, Kitamura K, Harada K (1981) Differences in subunit composition of glycinin among soybean cultivars. J Agric Food Chem 29:20-23. doi:10.1021/jf00103a006

Nakamura T, Utsumi S, Kitamura K, Harada K, Mori T (1984) Cultivar differences in gelling characteristics of soybean glycinin. J Agric Food Chem 32:647-651. doi:10.1021/jf00123a055

Napoli C, Lemieux C, Jorgensen R (1990) Introduction of a chimeric chalcone synthase gene into petunia results in reversible co-suppression of homologous genes in trans. Plant Cell 2:279-289. doi:10.1105/tpc.2.4.279

Narikawa T, Tamura T, Yagasaki K, Terauchi K, Sanmiya K, Ishimaru Y, Abe K, Asakura T (2010) Expression of the stress-related genes for glutathione S-transferase and ascorbate peroxidase in the most-glycinin-deficient soybean cultivar Tousan205 during Seed Maturation. Biosci Biotechnol Biochem 74:1976-1979. doi:10.1271/bbb.100479

Nielsen NC, Dickinson CD, Cho TJ, Thanh VH, Scallon BJ, Fischer RL, Sims TL, Drews GN, Goldberg RB (1989) Characterization of the glycinin gene family in soybean. Plant Cell 1:313-328. doi:10.1105/tpc.1.3.313 
Nishizawa K, Komatsu S (2011) Characteristics of soybean 1-Cys peroxiredoxin and its behavior in seedlings under flooding stress. Plant Biotechnol 28:83-88.

doi:10.5511/plantbiotechnology.10.1006a

Nishizawa K, Maruyama N, Satoh R, Fuchikami Y, Higasa T, Utsumi S (2003) A C-terminal sequence of soybean beta-conglycinin alpha ' subunit acts as a vacuolar sorting determinant in seed cells. Plant J 34:647-659. doi:10.1046/j.1365-313X.2003.01754.x

Niu Q-W, Lin S-S, Reyes JL, Chen K-C, Wu H-W, Yeh S-D, Chua N-H (2006) Expression of artificial microRNAs in transgenic Arabidopsis thaliana confers virus resistance. Nature Biotechnol 24:1420-1428. doi:10.1038/nbt1255

Niwa Y, Hirano T, Yoshimoto K, Shimizu M, Kobayashi H (1999). Non-invasive quantitative detection and applications of non-toxic, S65T-type green fluorescent protein in living plants. Plant J 18:455-463. doi: 10.1046/j.1365-313X.1999.00464.x

Ogawa T, Tayama E, Kitamura K, Kaizuma N (1989) Genetic-improvement of seed storage proteins using 3 variant alleles of 7S globulin subunits in soybean (Glycine-max L). Japanese J Breed 39:137-147

Ohtake N, Yamada S, Suzuki M, Takahashi N, Takahashi Y, Chinushi T, Ohyama T (1997) Regulation of accumulation of beta-subunit of beta-conglycinin in soybean seeds by nitrogen. Soil Sci Plant Nutrition 43:247-253

Pathan SM, Tri V, Clark K, Lee J-D, Shannon JG, Roberts CA, Ellersieck MR, Burton JW, Cregan $\mathrm{PB}$, Hyten Genetic mapping and confirmation of quantitative trait loci for seed protein and oil contents and seed weight in soybean. Crop Sci 53:765-774. doi:10.2135/cropsci2012.03.0153

Prak K, Nakatani K, Katsube-Tanaka T, Adachi M, Maruyama N, Utsumi S (2005) Structure-function relationships of soybean proglycinins at subunit levels. J Agric Food Chem 53:3650-3657. doi: 10.1021/jf047811x

Redondo-Cuenca A, Villanueva-Suarez MJ, Mateos-Aparicio I (2008) Soybean seeds and its by-product okara as sources of dietary fibre. Measurement by AOAC and Englyst methods. Food Chem 108:1099-1105. doi:10.1016/j.foodchem.2007.11.061

Samoto M, Maebuchi M, Miyazaki C, Kugitani H, Kohno M, Hirotsuka M, Kito M (2007) Abundant proteins associated with lecithin in soy protein isolate. Food Chem 102:317-322. doi:10.1016/j.foodchem.2006.05.054

Samoto M, Miyazaki C, Kanamori J, Akasaka T, Kawamura Y (1998) Improvement of the off-flavor of soy protein isolate by removing oil-body associated proteins and polar lipids. Biosci Biotechnol Biochem 62:935-940. doi:10.1271/bbb.62.935

Sato H, Yamada T, Kita Y, Ishimoto M, Kitamura K (2007) Production of transgenic plants and their early seed set in Japanese soybean variety, Kariyutaka. Plant Biotechnol 5:533-536

Scallon B, Thanh VH, Floener LA, Nielsen NC (1985) Identification and characterization of DNA clones encoding group-II glycinin subunits. Theor Appl Genet 70:510-519. 
doi:10.1007/bf00305984

Schmidt MA, Barbazuk WB, Sandford M, May G, Song Z, Zhou W, Nikolau BJ, Herman EM (2011) Silencing of soybean seed storage proteins results in a rebalanced protein composition preserving seed protein content without major collateral changes in the metabolome and transcriptome. Plant Physiol 156:330-345. doi:10.1104/pp.111.173807

Schmidt MA, Herman EM (2008) Proteome rebalancing in soybean seeds can be exploited to enhance foreign protein accumulation. Plant Biotechnol J 6:832-842. doi:10.1111/j.1467-7652.2008.00364.x

Sebolt AM, Shoemaker RC, Diers BW (2000) Analysis of a quantitative trait locus allele from wild soybean that increases seed protein concentration in soybean. Crop Sci 40:1438-1444

Shi A, Chen P, Zhang B, Hou A (2010a) Genetic diversity and association analysis of protein and oil content in food-grade soybeans from Asia and the United States. Plant Breed 129:250-256. doi:10.1111/j.1439-0523.2010.01766.x

Shi R, Yang C, Lu S, Sederoff R, Chiang VL (2010b) Specific down-regulation of PAL genes by artificial microRNAs in Populus trichocarpa. Planta 232:1281-1288. doi:10.1007/s00425-010-1253-3

Shibata M, Takayama K, Ujiie A, Yamada T, Abe J, Kitamura K (2008) Genetic relationship between lipid content and linolenic acid concentration in soybean seeds. Breed Sci 58:361-366. doi:10.1270/jsbbs.58.361

Sorgentini DA, Wagner JR (1999) Comparative study of structural characteristics and thermal behavior of whey and isolate soybean proteins. J Food Biochem 23:489-507. doi:10.1111/j.1745-4514.1999.tb00033.x

Takahashi K, Banba H, Kikuchi A, Ito M, Nakamura S (1994) An induced mutant line lacking the alpha-subunit of beta-conglycinin in soybean Glycine-max (L) Merrill. Breed Sci :65-66

Takahashi M, Uematsu Y, Kashiwaba K, Yagasaki K, Hajika M, Matsunaga R, Komatsu K, Ishimoto M (2003) Accumulation of high levels of free amino acids in soybean seeds through integration of mutations conferring seed protein deficiency. Planta 217:577-586. doi:10.1007/s00425-003-1026-3

Tezuka M, Taira H, Igarashi Y, Yagasaki K, Ono T (2000) Properties of tofus and soy milks prepared from soybeans having different subunits of glycinin. J Agric Food Chem 48:1111-1117. doi:10.1021/jf9905601

Thanh VH, Shibasaki K (1976) Major proteins of soybean seeds - straightforward fractionation and their characterization. J Agric Food Chem 24:1117-1121

Thanh VH, Shibasaki K (1978) Major proteins of soybean seeds - reconstitution of beta-conglycinin from its subunits. J Agric Food Chem 26:695-698

Toppino L, Kooiker M, Lindner M, Dreni L, Rotino GL, Kater MM (2011) Reversible male sterility in eggplant (Solanum melongena L.) by artificial microRNA-mediated silencing of general 
transcription factor genes. Plant Biotechnol J 9:684-692.

doi:10.1111/j.1467-7652.2010.00567.x

Tsubokura Y, Hajika M, Kanamori H, Xia Z, Watanabe S, Kaga A, Katayose Y, Ishimoto M, Harada $\mathrm{K}$ (2012) The beta-conglycinin deficiency in wild soybean is associated with the tail-to-tail inverted repeat of the alpha-subunit genes. Plant Mol Biol 78:301-309.

doi:10.1007/s11103-011-9865-y

Vanderriet WB, Wight AW, Cilliers JJL, Datel JM (1989) Food chemical investigation of tofu and its by-product okara. Food Chem 34:193-202. doi:10.1016/0308-8146(89)90140-4

Wadahama H, Iwasaki K, Matsusaki M, Nishizawa K, Ishimoto M, Arisaka F, Takagi K, Urade R (2012) Accumulation of beta-conglycinin in soybean cotyledon through the formation of disulfide bonds between alpha '- and alpha-subunits. Plant Physiol 158:1395-1405. doi:10.1104/pp.111.189621

Warthmann N, Chen H, Ossowski S, Weigel D, Herve P (2008) Highly specific gene silencing by artificial miRNAs in Rice. Plos One 3. doi:10.1371/journal.pone.0001829

Yamada T, Watanabe S, Arai M, Harada K, Kitamura K (2010) Cotyledonary node pre-wounding with a micro-brush increased frequency of Agrobacterium-mediated transformation in soybean. Plant Biotechnol 27:217-220

Yamada T, Ohashi Y, Ohshima M, Inui H, Shiota N, Ohkawa H, Ohkawa Y (2002) Inducible cross-tolerance to herbicides in transgenic potato plants with the rat CYP1A1 gene. Theor Appl Genet 104:308-314. doi: 10.1007/s001220100736

Zhang B, Chen P, Florez-Palacios SL, Shi A, Hou A, Ishibashi T (2010) Seed quality attributes of food-grade soybeans from the US and Asia. Euphytica 173:387-396. doi:10.1007/s10681-010-0126-y

Zhang B, Pan X, Stellwag EJ (2008) Identification of soybean microRNAs and their targets. Planta 229:161-182. doi:10.1007/s00425-008-0818-x 


\section{Figure legends}

Fig. 1. Target sequences of the amiRNAs and expression vector construction. a Complementarity between the sequences of the three designed amiRNAs (amiR-7S-A, amiR-7S-B, and amiR-7S-C) and the target transcript sequences of six 7S globulin subunit genes. Mismatches between the amiRNA and target sequences are indicated by gray characters. b Expression vector construction by overlapping PCR. The first PCR was conducted to replace miR159a and miR159a (antisense miR159a) with amiR-7S and amiR-7S* (antisense amiR-7S), respectively. The second PCR was carried out using three PCR products containing overlapping sequences (gray bars) as template DNA to arrange amiR-7S and amiR-7S ${ }^{*}$ in the frame of the gma-miR159a precursor. The overlapping PCR was performed under the following conditions: 35 cycles of $95^{\circ} \mathrm{C}$ for $30 \mathrm{~s}, 58^{\circ} \mathrm{C}$ for $30 \mathrm{~s}$ and $72^{\circ} \mathrm{C}$ for $20 \mathrm{~s}$. The PCR products were inserted into an expression vector.

Fig. 2. SDS-PAGE and immunoblot analysis of mature seeds of amiR-7S plants. a Protein extracts from mature seeds of nine 7S-A ( $\mathrm{T}_{3}$ seeds), 7S-B ( $\mathrm{T}_{2}$ seeds), and 7S-C ( $\mathrm{T}_{2}$ seeds) independent plants were subjected to SDS-PAGE. Arrowheads indicate $\alpha^{\prime}, \alpha$, and $\beta$ subunits of 7S-globulins. $\mathbf{b}$ Immunoblot analysis with antisera against each $7 \mathrm{~S}$ globulin subunit $\left(\alpha^{\prime}, \alpha\right.$, and $\left.\beta\right)$.

Fig. 3. Expression analysis of 7S globulin genes in 7S-A plants. a Expression levels of $\alpha$-subunit genes (Glyma20g28650 and Glyma20g28660). b Expression levels of $\alpha^{\prime}$-subunit gene (Glyma10g39150).c Expression levels of $\alpha^{\prime}$-subunit gene (Glyma10g39170). d Expression levels of $\beta$-subunit genes (Glyma20g28460 and Glyma20g28640). All expression levels were determined by normalizing the PCR threshold cycle number of each target gene to that of the $\beta$-tubulin gene (Glyma08g01740) as a reference gene. Data are means \pm SD of three independent experiments.

Fig. 4. Expression analysis of endogenous gma-miR159a and production of amiR-7S-A in 7S-A-2 seeds. a The region of endogenous gma-miR159a amplified by qRT-PCR is shown by a dashed bidirectional arrow. The specific probe region for detection of amiR-7S-A production is shown by a solid bidirectional arrow. b Relative expression level determined by normalizing the PCR threshold cycle number of gma-miR159a to that of the $\beta$-tubulin gene (Glyma08g01740). Data are means \pm SD of three independent experiments. c Northern blot analysis with the probe labeled at the 3 '-end with DIG. The bottom panel shows ethidium bromide staining of $5 \mathrm{~S}$ and $5.8 \mathrm{~S}$ rRNAs as loading control.

Fig. 5. Nitrogen (a), carbon (b), and lipid (c) contents in mature 7S-A seeds. Data are means \pm SD of three independent experiments.

Fig. 6. Nitrogen content in each protein fraction of defatted 7S-A seeds. a Whey fraction. b Major 
soluble protein fraction. $\mathbf{c}$ Residual fraction. $\mathbf{d}$ Lipophilic fraction. Data are means \pm SD of three independent experiments.

Fig. 7. Nitrogen content derived from amino acids in the residual fraction of 7S-A seeds. a Nitrogen content from total amino acids. b Nitrogen content from free amino acids. Data are means \pm SD of three replicates for two 7S-A and two control plants.

Fig. 8. Morphological characteristics of the organelles in mature seeds examined by electron microscopy. a Control. b 7S-A. c Immunoelectron microscopic analysis of a mature 7S-A seed using specific antibody against $\mathrm{A}_{1 \mathrm{a}} \mathrm{B}_{1 \mathrm{~b}}$. PSV, protein storage vacuole; $\mathrm{OB}$, oil body; Bars, $1 \mu \mathrm{m}$. 
2

\begin{tabular}{|c|c|}
\hline amiR- & 3' ACGGCUCUUGUUGGUCUCCUU $5^{\prime}$ \\
\hline Glyma20g28650 & $5^{\prime} \ldots$ UGCCGAGAACAACCAGAGGAA ...3 \\
\hline lyma20g28660 & 5'...UGCCGAGAACAACCAGAGGAA ...3 \\
\hline lyma10g39150 & $5^{\prime} \ldots$ UGCCGAGAACAACCAGAGGAA...3 \\
\hline lyma10g39170 & $5^{\prime} \ldots$ UGC GAGAACAACCAGAGGAA...3 \\
\hline lyma20g28460 & $5^{\prime}$...UGC GAGAACAACCAGAGGAA...3' \\
\hline lyma20g28640 & $5^{\prime}$...UGC GAGAACAACCAGAGGAA...3' \\
\hline $\operatorname{miR}-7 \mathrm{~S}-\mathrm{B}$ & 3' GUCAAAGACAGAGUAAACCGU 5' \\
\hline 1 yma20g28650 & $5^{\prime} . . . C A G U U U C U G U C U C A U U U G G C A \ldots 3^{\prime}$ \\
\hline Glyma20g28660 & $5^{\prime} \ldots$...AGUUUCUGUCUCAUUUGGCA...3 ' \\
\hline Glyma10g39150 & $5^{\prime} \ldots$...AGUUUCUGUCUCAUUUGGCA ...3 ' \\
\hline Glyma10g39170 & $5^{\prime}$...CAGUUUCUGUCUCAUUACAGG...3 ' \\
\hline Glyma20g28460 & $5^{\prime} \ldots$...AGUUU $\in$ UCUGUCAUUAAAGG. $.3{ }^{\prime}$ \\
\hline Glyma20g28640 & $5^{\prime} \ldots$...CAGUUU $\in U G U C U C A U U A A A G G \ldots 3^{\prime}$ \\
\hline MIR- $12-C$ & 3' GUUAAGGGUAAGGGUGCGGGU 5' \\
\hline Glyma20g28650 & $5^{\prime} \ldots$...AAUUCCCAUUCCCACGCCCA...3' \\
\hline Glyma20g28660 & $5^{\prime} \ldots$...AAUUCCCAUUCCCACGCCCA...3' \\
\hline Glyma10g39150 & $5^{\prime} \ldots$ GAACACCCA CCCCAC CC A...3' \\
\hline Glyma10g39170 & $------\ldots 3^{\prime}$ \\
\hline Glyma20g28460 & $-------\ldots 3$ \\
\hline lyma20g28640 & $--------\ldots 3$ \\
\hline
\end{tabular}

b

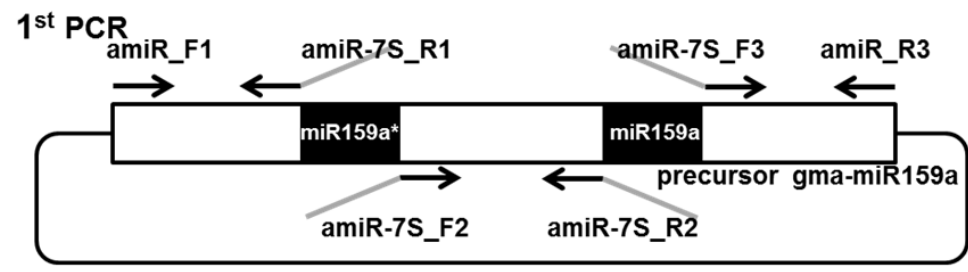

$2^{\text {nd }} P C R$

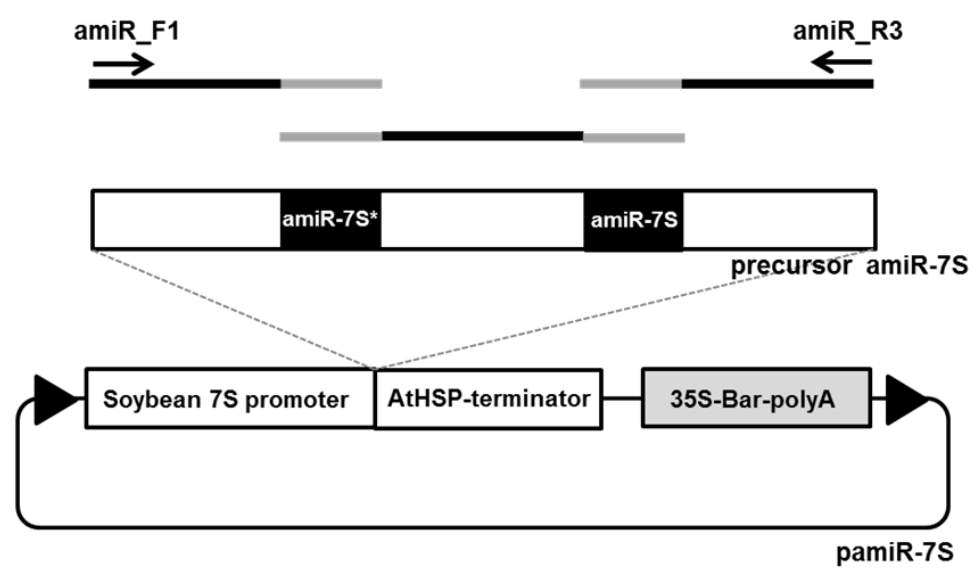


a

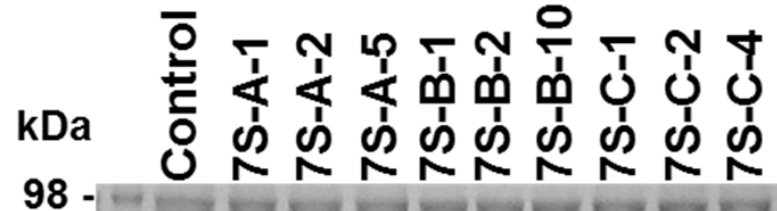

64.

$50-\beta$ -

36 -

22 -

16 .

6 -

b

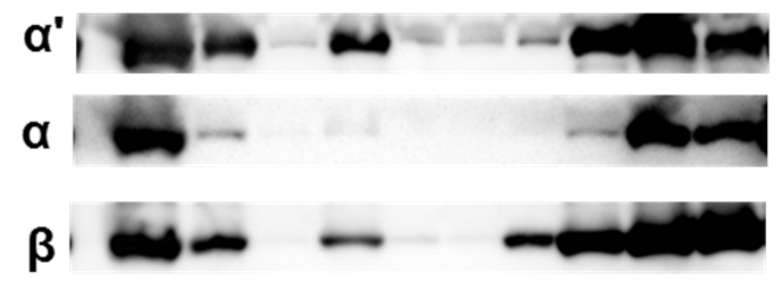


a

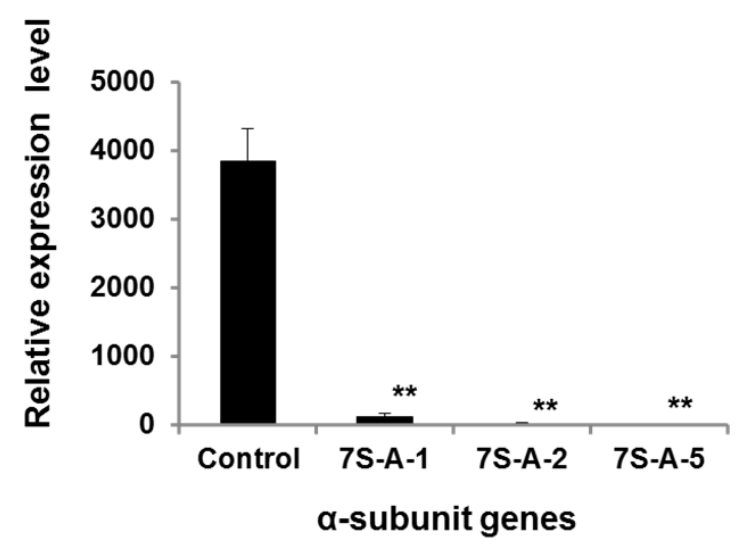

b

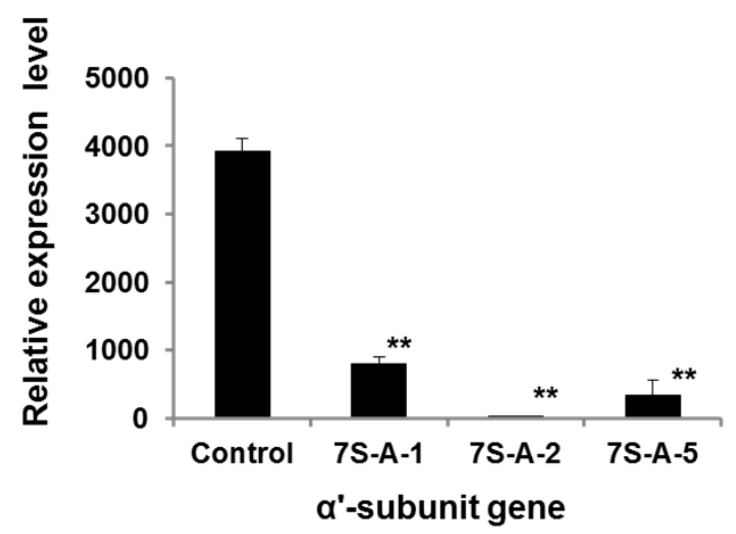

C

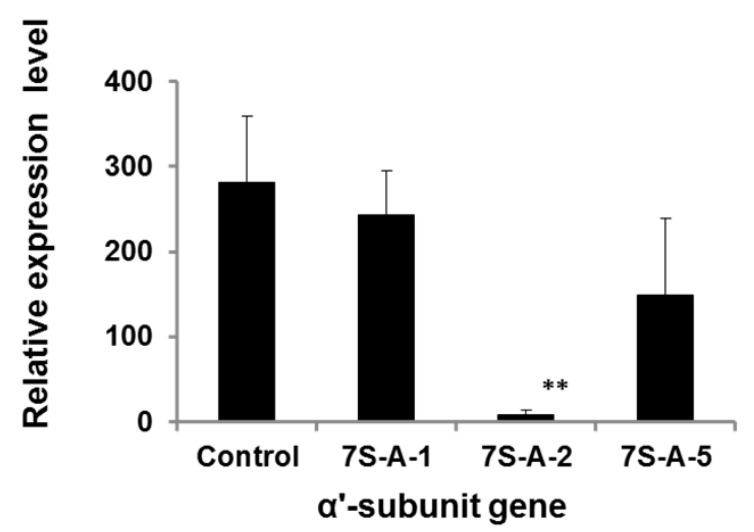

d

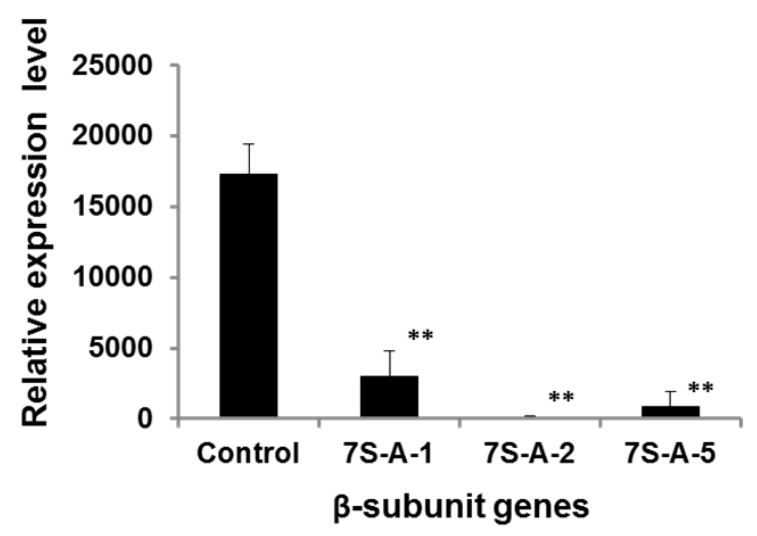


a

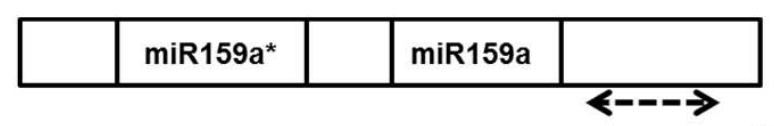

precursor gma-miR159a

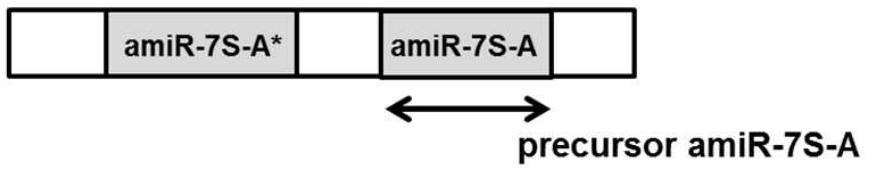

b

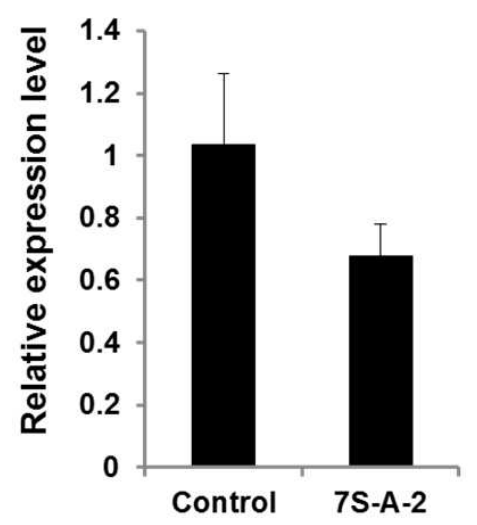

C

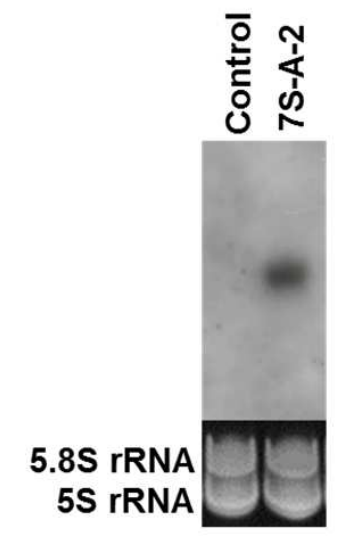


a

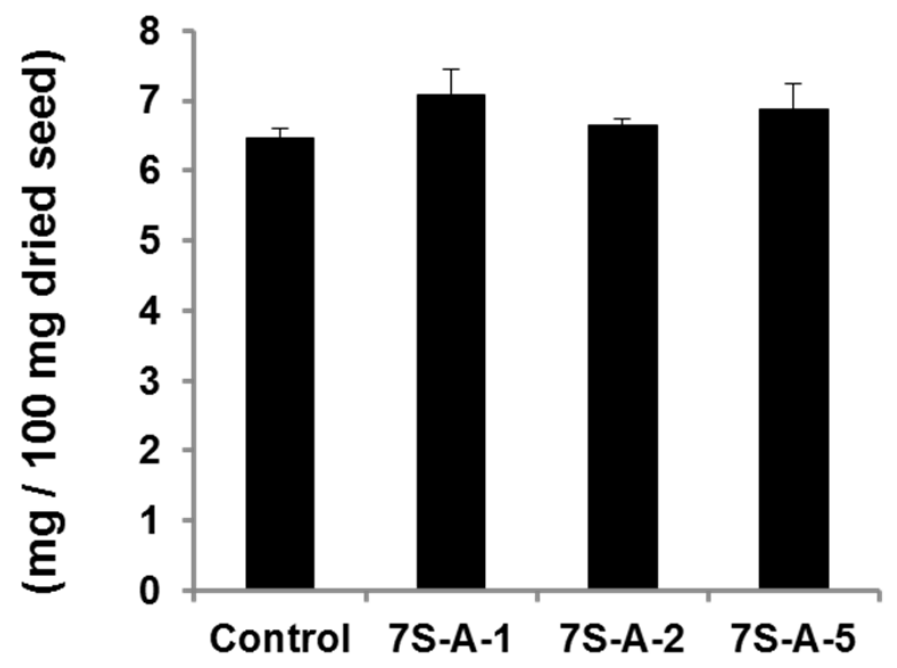

b

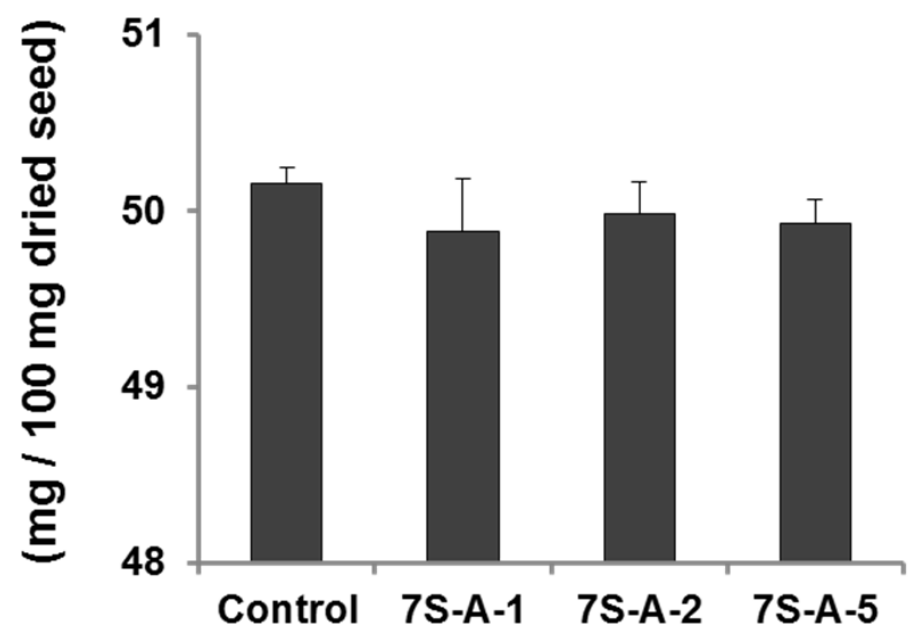

C

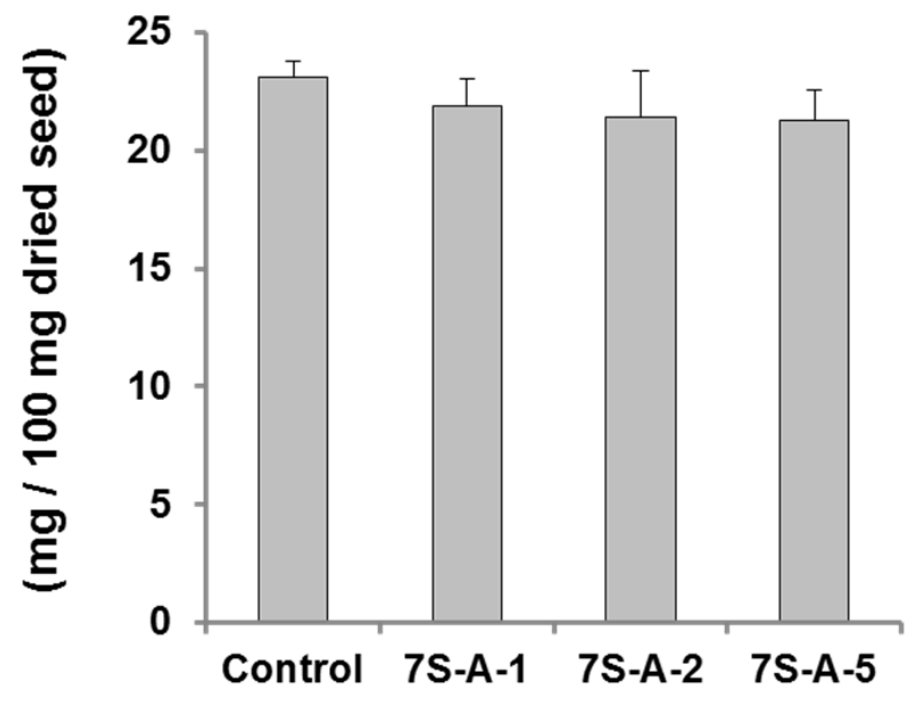




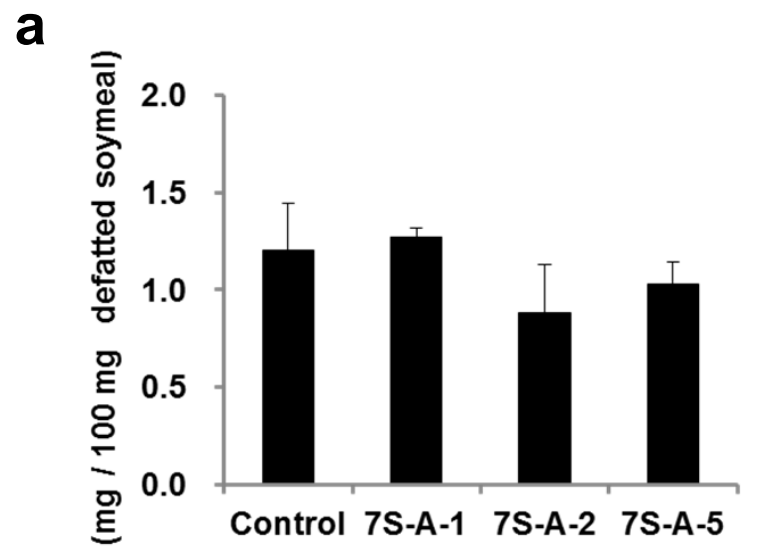

b

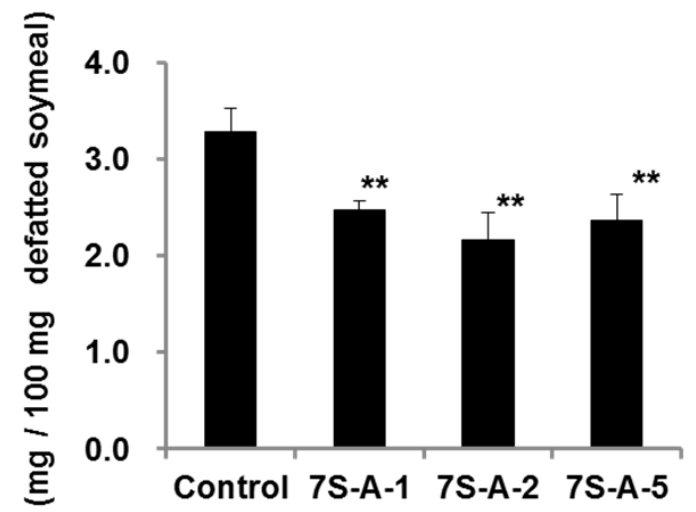

C

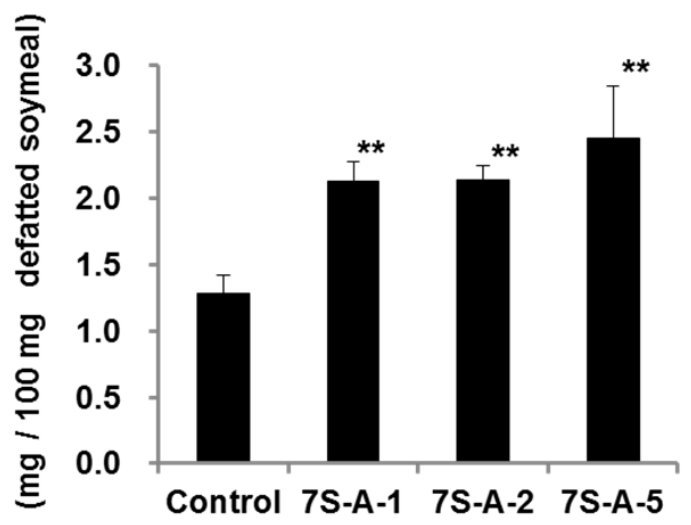

d

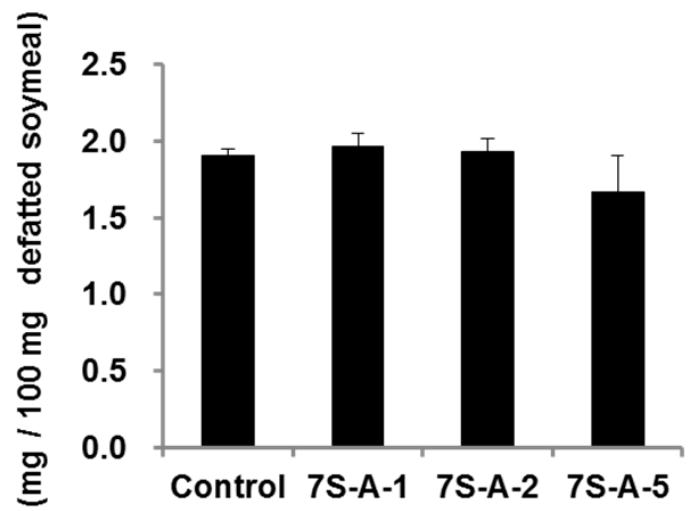


a

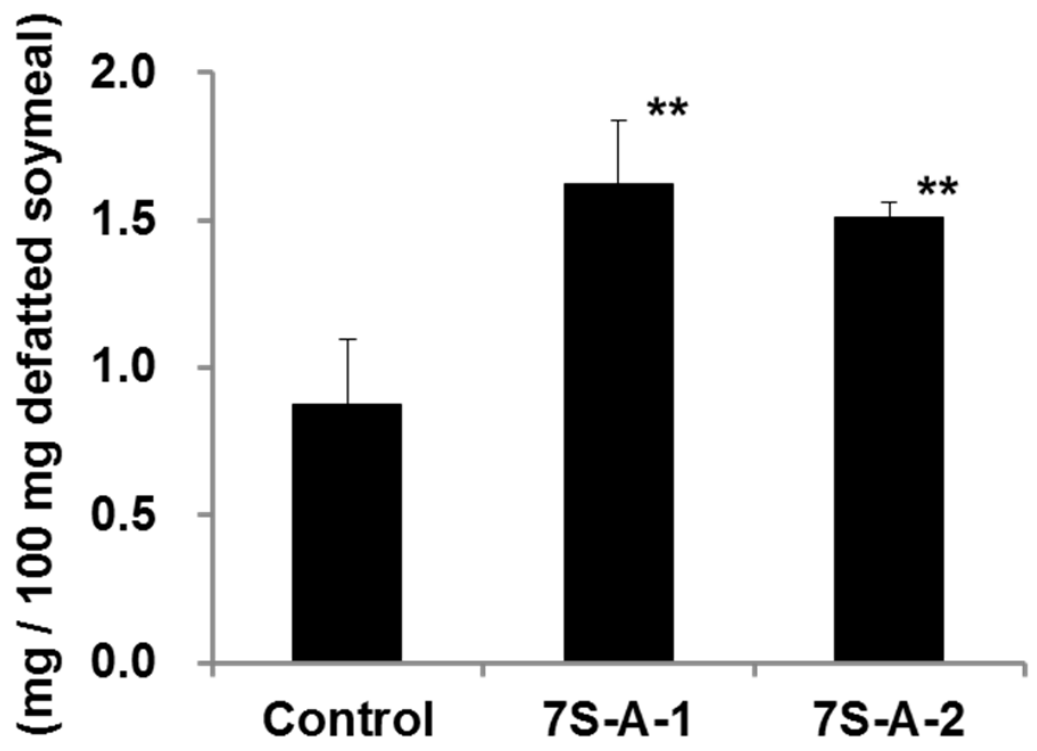

b

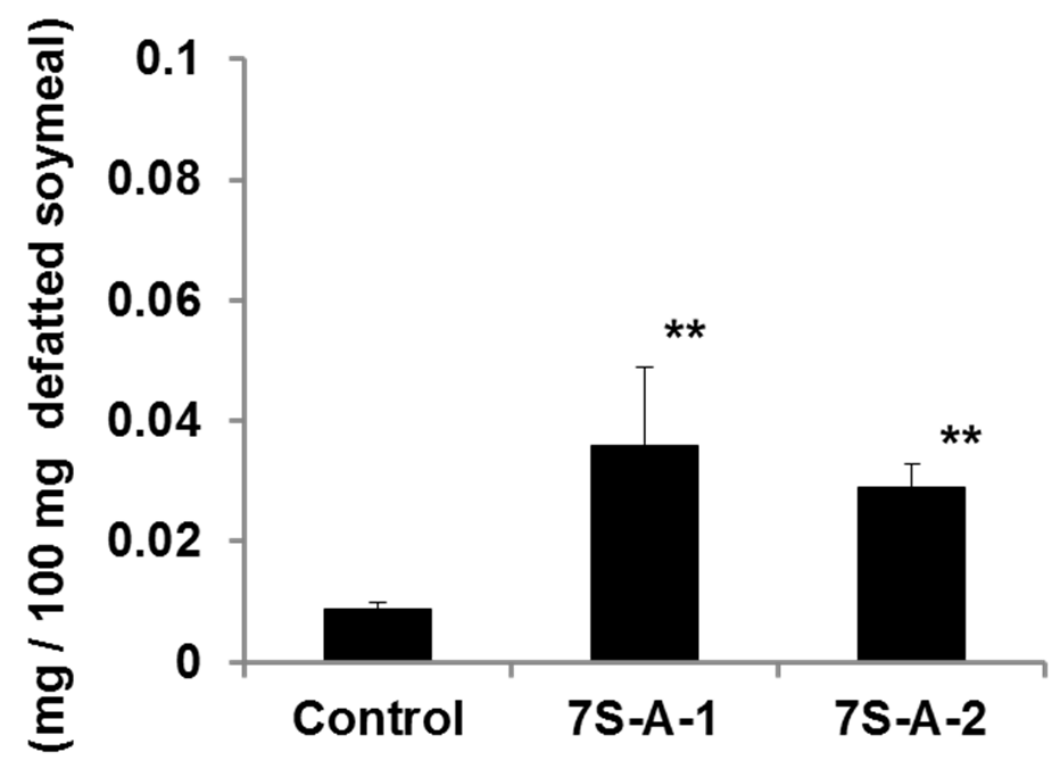



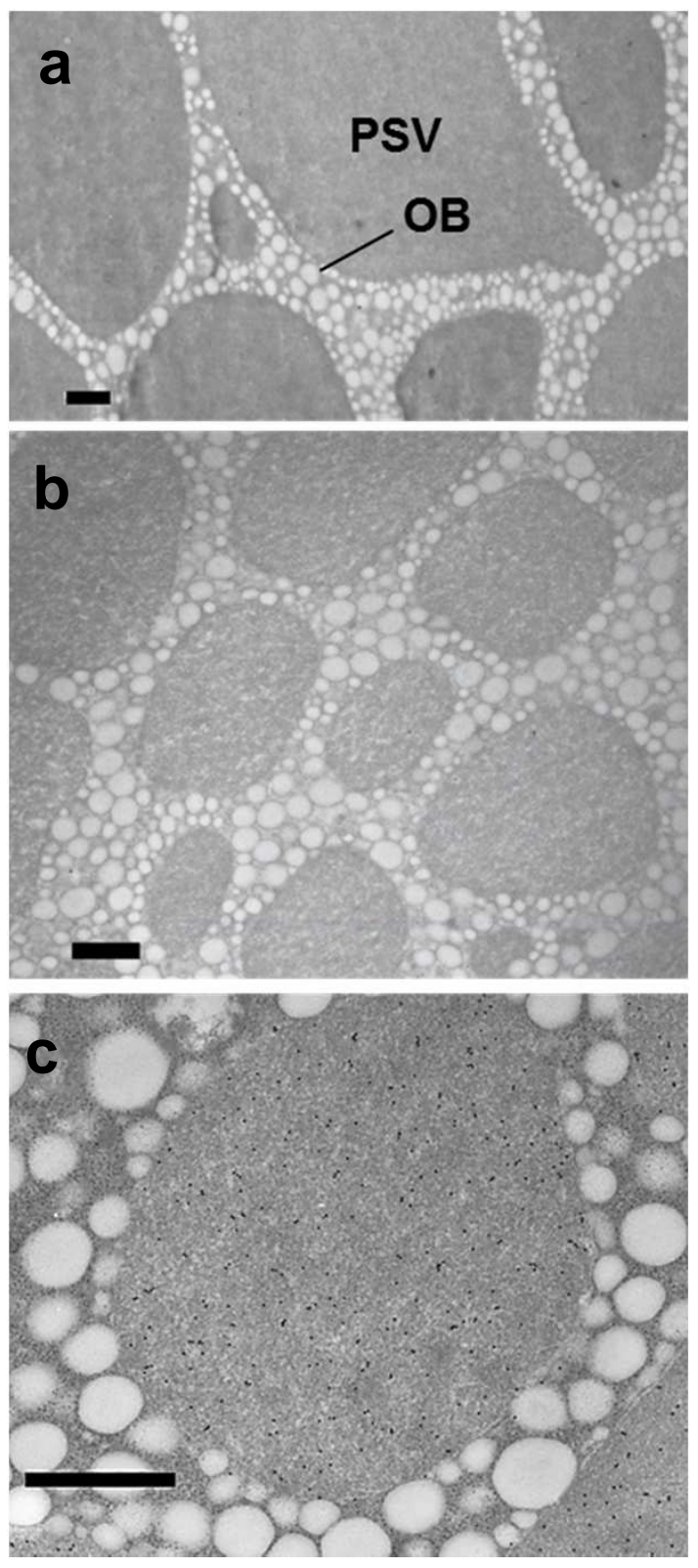


\section{Supplementary materials}

\section{Article title:}

Knock-down of the $7 \mathrm{~S}$ globulin subunits shifts distribution of nitrogen sources to the residual protein fraction in transgenic soybean seeds

\section{Journal name:}

\section{Plant Cell Reports}

\section{Authors:}

Tetsuya Yamada Y Yoshihiro Mori · Kazuho Yasue $\cdot$ Nobuyuki Maruyama $\cdot$ Keisuke Kitamura $\cdot$ Jun Abe

Y. Yamada $\cdot$ Y. Mori $\cdot$ K. Kitamura $\cdot$ J. Abe

Graduate School of Agriculture, Hokkaido University, Kita9 Nishi9, Kita-ku, Sapporo, Hokkaido 060-8589, Japan

K. Yasue

School of Agriculture, Hokkaido University, Kita9 Nishi9, Kita-ku, Sapporo, Hokkaido 060-8589, Japan

N. Maruyama

Graduate School of Agriculture, Kyoto University, Uji, Kyoto 611-011, Japan

\section{Corresponding author:}

T. Yamada

Tel. +81 11 706-4186; fax +81 11 706-4933; e-mail: tetsuyay@ res.agr.hokudai.ac.jp 
Table S1. Primer sequences used in this study

\begin{tabular}{|c|c|c|}
\hline Primer name & Primer sequence $\left(5^{\prime}-3^{\prime}\right)$ & Use of amplicon \\
\hline Gm-amiR_F1 & GCTCTAGAGCGCTAGCTAGGGTTTGGGTAGTG & vector construction \\
\hline Gm-amiR_R3 & GCGAGCTCGACATGCACATACCTCGGACAAGG & vector construction \\
\hline amiR-7S-A_R1 & CAATCCTCTGCATGTTCTCGGCACTTCATAATCCCCTTTAATTAATGTTTCCC & 7S-A amiR vector construction \\
\hline amiR-7S-A_F2 & AGTGCCGAGAACATGCAGAGGATTGAGGATCTTACTGGGTGAATTGAG & $\begin{array}{l}\text { 7S-A amiR vector construction, } \\
\text { Probe }^{* 1}\end{array}$ \\
\hline amiR-7S-A_F3 & тCTTCCTCTGGTTGTTCTCGGCACACCCTTCTCTTCTTTTCTCTC & $7 \mathrm{~S}-\mathrm{A}$ amiR vector construction \\
\hline amiR-7S-B_R1 & CAAGCCAAATCTGACAGAAACTGCTTCATAATCCCСТTTAATTAATGTTTCCC & $7 \mathrm{~S}-\mathrm{B}$ amiR vector construction \\
\hline amiR-7S-B_F2 & AGCAGTTTCTGTCAGATTTGGCTTGAGGATCTTACTGGGTGAATTGAG & 7S-B amiR vector construction \\
\hline amiR-7S-B_R2 & TGCAGTTTCTGTCTCATTTGGCAGAAGGTTAATACTATAAAGGCAAATG & 7S-B amiR vector construction \\
\hline amiR-7S-C_R1 & CAAGGTCGTGGAGGTGGAATTTCCTTCATAATCCCСTTTAATTAATGTTTCCC & 7S-C amiR vector construction \\
\hline amiR-7S-C_F2 & AGGAAATTCCACCTCCACGACCTTGAGGATCTTACTGGGTGAATTGAG & 7S-C amiR vector construction \\
\hline amiR-7S-C_R2 & TGGAAATTCCACGACCACGACCAGAAGGTTAATACTATAAAGGCAAATG & 7S-C amiR vector construction \\
\hline amiR-7S-C_F3 & TCTGGTCGTGGTCGTGGAATTTCCACCСTTCTCTTCTTTTCTCTC & 7S-C amiR vector construction \\
\hline$\alpha$-alike487_ReTiF1 & AGGATGAGGAACAAGATGAACGTCAATTC & qRT-PCR \\
\hline a-alike581_ReTiR1 & GCAGCGAGAGAGCGAAGAAAGTGAAGAT & qRT-PCR \\
\hline ap-485_ReTiF1 & CAAGATGAACGTGAACACCCAC & qRT-PCR \\
\hline ap-662_ReTiR1 & ATTCTTATGTCTTCGTGGTTCTCTTTG & qRT-PCR \\
\hline ap-like1496_ReTiF1 & CAGCAACAGGGAGAGGAAACAAGGG & qRT-PCR \\
\hline
\end{tabular}


Table S1 Continued

\begin{tabular}{|c|c|c|}
\hline Primer name & Primer sequence $\left(5^{\prime}-3^{\prime}\right)$ & Use of amplicon \\
\hline ap-like1697_ReTiR1 & CGCAAGCTCCTTCACCTGTTTTTG & qRT-PCR \\
\hline$\beta$ - $\beta$ like1345_ReTiF1 & TGCTCTCTACTGAATAACTACGTAAATGT & qRT-PCR \\
\hline$\beta$ - $\beta$ like1411_ReTiR1 & AGCTCAAGTTTTTATAGTTACATGGGC & qRT-PCR \\
\hline miR159a366_ReTiF1 & GAAGTTTTTCCGTTTTTCTCTTTTGCCATGATC & qRT-PCR \\
\hline miR159a461_ReTiR1 & AACCTCACCTTCGTGATGCACAC & qRT-PCR \\
\hline$\beta$-tubulinR1 & TCAGTCACATCCACATTCAGGG & qRT-PCR \\
\hline
\end{tabular}

Underlines indicate the Xba I and Sac I restriction sites, respectively, for directional cloning in binary vector of soybean transformation.

${ }^{* 1}$ DNA fragment amplified with these primers set was used to prepare the specific probe for Southern blot analysis in transgenic soybean plants. 
Table S2. Free amino acid content in residual fraction of 7S-A and control seeds

\begin{tabular}{|c|c|c|c|}
\hline \multirow{2}{*}{$\begin{array}{l}\text { Amino acids } \\
(\mu \mathrm{g} / 100 \mathrm{mg} \text { defatted meal) }\end{array}$} & \multicolumn{3}{|l|}{ Plant lines } \\
\hline & Control & 7S-A-1 & $7 \mathrm{~S}-\mathrm{A}-1$ \\
\hline Ala & $3.554 \pm 0.935$ & $8.384 \pm 2.204^{*}$ & $7.485 \pm 1.103 *$ \\
\hline $\operatorname{Arg}$ & $7.169 \pm 1.243$ & $43.886 \pm 21.848^{*}$ & $34.850 \pm 6.335$ \\
\hline Asn & $1.297 \pm 0.215$ & $5.147 \pm 2.166^{*}$ & $4.409 \pm 0.932$ \\
\hline Asp & $2.514 \pm 0.866$ & $3.615 \pm 1.409$ & $2.888 \pm 0.618$ \\
\hline Cys & $4.256 \pm 1.022$ & $7.418 \pm 1.040$ & $2.574 \pm 4.424$ \\
\hline Gln & $1.170 \pm 0.290$ & $3.080 \pm 1.084^{*}$ & $2.676 \pm 0.244$ \\
\hline Glu & $5.836 \pm 0.573$ & $18.978 \pm 1.391 * *$ & $17.696 \pm 3.203 * *$ \\
\hline Gly & $1.333 \pm 0.345$ & $3.672 \pm 0.958 * *$ & $3.489 \pm 0.120 *$ \\
\hline His & $1.292 \pm 0.197$ & $3.330 \pm 0.874 * *$ & $3.065 \pm 0.358^{*}$ \\
\hline Ile & $1.582 \pm 0.313$ & $2.987 \pm 0.946$ & $2.807 \pm 0.319$ \\
\hline Leu & $1.388 \pm 0.401$ & $2.756 \pm 0.884$ & $2.721 \pm 0.066$ \\
\hline Lys & $3.731 \pm 0.710$ & $7.789 \pm 2.036^{*}$ & $7.050 \pm 0.482 *$ \\
\hline Met & $0.120 \pm 0.139$ & $0.342 \pm 0.226$ & $0.379 \pm 0.134$ \\
\hline Phe & $3.110 \pm 0.568$ & $10.233 \pm 1.509 * *$ & $7.481 \pm 1.973 *$ \\
\hline Pro & $0.657 \pm 0.631$ & $3.161 \pm 1.190^{*}$ & $2.811 \pm 0.583^{*}$ \\
\hline Ser & $1.573 \pm 0.411$ & $3.557 \pm 1.046^{*}$ & $3.266 \pm 0.052 *$ \\
\hline Thr & $3.038 \pm 0.782$ & $5.934 \pm 1.756^{*}$ & $6.244 \pm 0.281^{*}$ \\
\hline Trp & $0.958 \pm 0.649$ & $6.812 \pm 1.210^{* *}$ & $3.974 \pm 0.805^{*}$ \\
\hline Tyr & $3.505 \pm 0.743$ & $8.214 \pm 1.148^{* *}$ & $7.021 \pm 1.047 *$ \\
\hline Val & $1.153 \pm 0.381$ & $2.428 \pm 0.683^{*}$ & $2.516 \pm 0.078^{*}$ \\
\hline Total & $49.237 \pm 8.329$ & $151.724 \pm 35.551 * *$ & $125.403 \pm 15.195 *$ \\
\hline
\end{tabular}

Data are mean $\pm \mathrm{SD}$ from three replicates for two 7S-A and control plants, respectively.

$* P<0.05 ; * * P<0.01$; with respect to the control. 


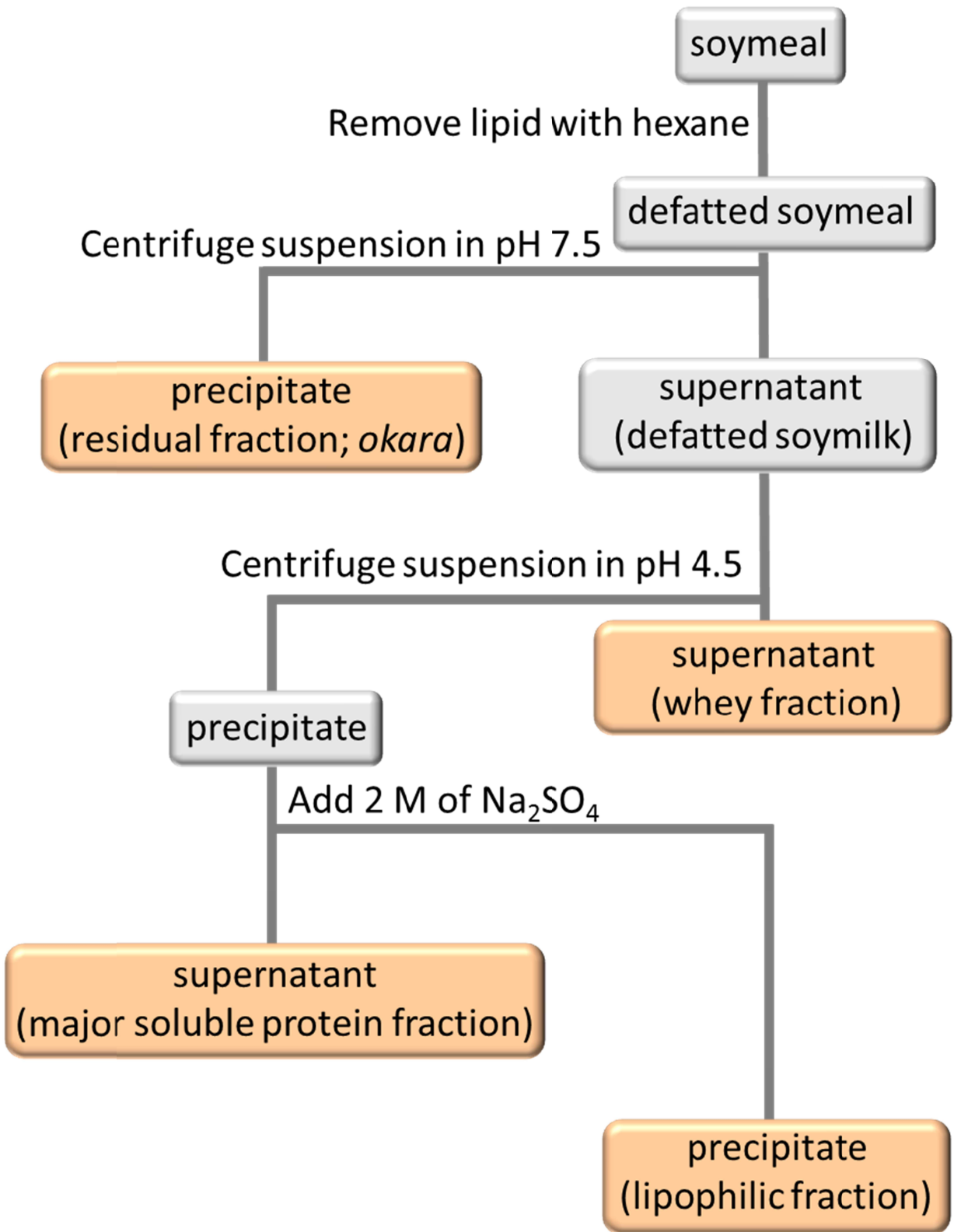

Fig. S1. Procedure of four protein fractions separated on the basis of differences in protein solubility at different $\mathrm{pH}$.

Soymeal was a fine powder of mature seeds. Residual, whey, major soluble protein (MSP), and lipophilic (LP) fractions were used to examine the distribution of protein and nitrogen. 
a

\begin{tabular}{|c|c|c|c|}
\hline $\begin{array}{c}\text { Soybean7S } \\
\text { promoter }\end{array}$ & 7S-A amiR' & 7S-A amiR & $\begin{array}{c}\text { AtHSP } \\
\text { terminator }\end{array}$ \\
\hline
\end{tabular}

b

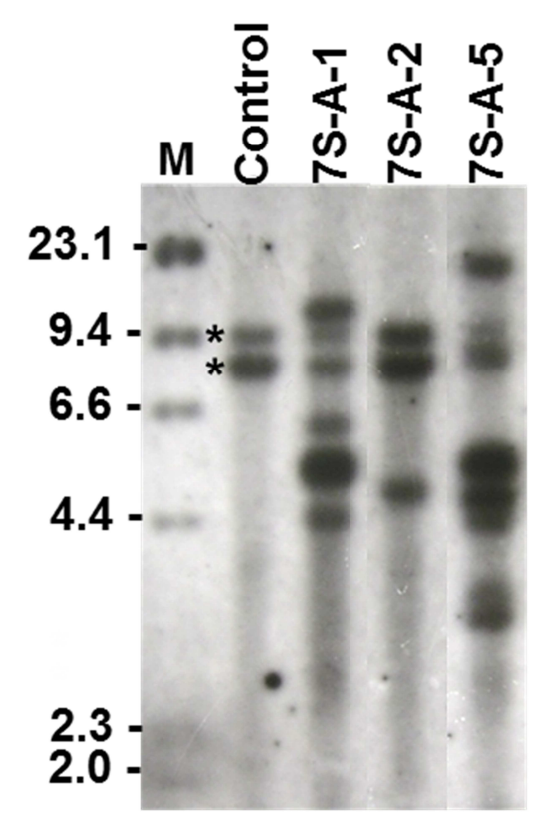

Fig. S2. Southern blot analysis of 7S-A plants.

a The specific probe region for the detection of transgene is shown by a solid bidirectional arrow. b Southern blot profile. Approximately $10 \mu \mathrm{g}$ of DNA digested with Xba I and subjected to electrophoresis in $0.8 \%$ agarose gels. Asterisks indicate signal bands hybridized with endogenous gma-miR159a. Lane M; $\lambda$ DNA digested with Hin dIII. 


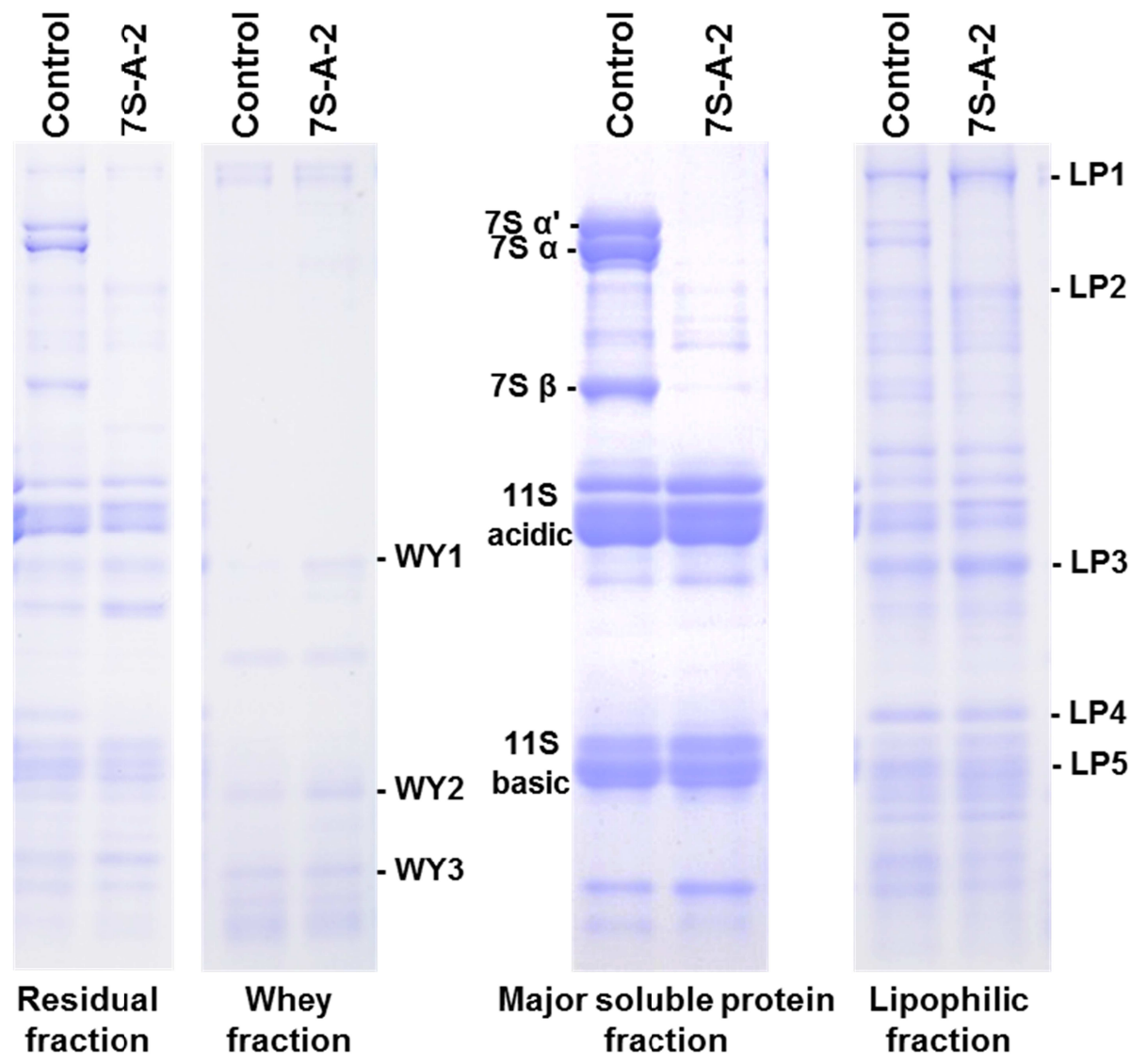

Fig. S3. SDS-PAGE profiles of each protein fraction of 7S-A seeds.

Total four fractions were separated by the process shown in Fig. S2. Amount of 9.2 and 6.0 $\mu \mathrm{g}$ samples were applied to SDS-PAGE in the Residual and LP fractions, respectively. Samples from $40 \mu \mathrm{g}$ of seed meal were separated by SDS-PAGE in the whey and MSP fractions. WY1, WY2, and WY3 indicated protein bands with similar molecular weight size of lectin, kunitz trypsin inhibitor, and Bowman-Brik trypsin inhibitor, respectively in the whey proteins reported by Sorgentini and Wagner (1999). LP1, LP2, LP3, LP4, and LP5 in the LP fraction were identical for the molecular weight size of lipoxygenase, $\gamma$-conglycinin, three oil body associated proteins $(34,24$, and $18 \mathrm{kDa}$ ), respectively described by Samoto et al. (1998). 


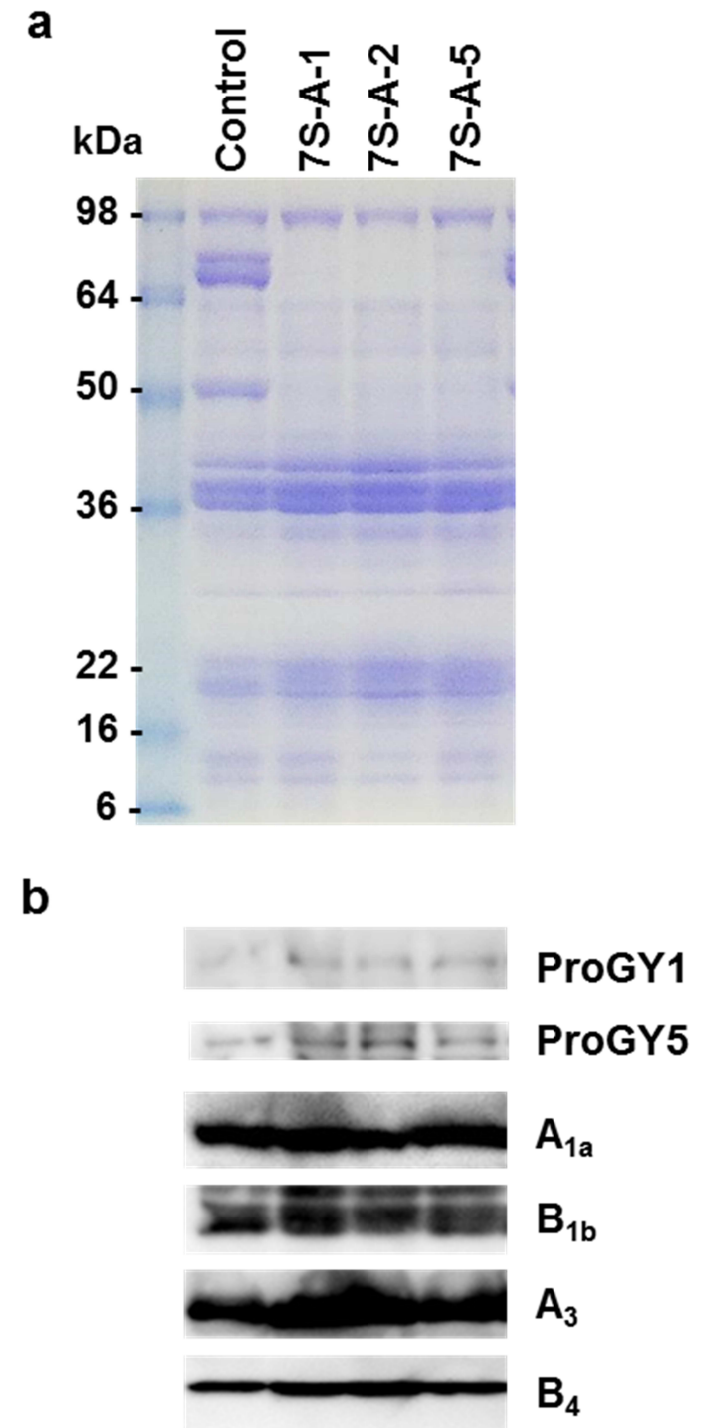

Fig. S4. SDS-PAGE and Immunoblot analysis in mature seeds of 7S-A plants.

a Proteins from $20 \mu \mathrm{g}$ soybean meal were separated by SDS-PAGE. b They were transferred to a PVDF membrane. The blot was probed with antibodies against $\mathrm{A}_{1 \mathrm{a}} \mathrm{B}_{1 \mathrm{~b}}$ or $\mathrm{A}_{3} \mathrm{~A}_{4}$ subunits of $11 \mathrm{~S}$ globulin. ProGY1 and ProGY5 indicates the precursors of $\mathrm{A}_{1 \mathrm{a}} \mathrm{B}_{1 \mathrm{~b}}$ and $A_{3} A_{4}$, respectively. $A_{1 a} B_{1 b}$ and $A_{3} B_{4}$ subunits were divided into four fragments: $A_{1 a}$, $\mathrm{B}_{1 \mathrm{~b}}, \mathrm{~A}_{3}$, and $\mathrm{B}_{4}$ by the protein processing in soybean seeds. 